\title{
The mortality and morbidity of deep sea fishermen sailing from Grimsby in one year ${ }^{1}$
}

\author{
S. R. W. MOORE' \\ The Health Department, Kingston upon Hull
}

Moore, S. R. W. (1969). Brit. J. industr. Med., 26, 25-46. The mortality and morbidity of deep sea fishermen sailing from Grimsby in one year. The injuries, illnesses, and deaths of Grimsby deep sea fishermen in the year 1963 have been studied using the trawler log-book as the basic source of information. Additional information has been obtained from other sources.

The numbers of man-days sailed by Grimsby deep sea fishermen, by age and rating in 1963, have been ascertained. From these, incapacity rates for the measurement of morbidity due to injury and illness, and the mortality rate, have been calculated.

There were 14 deaths, six due to accidental causes and eight to natural causes, giving a mortality rate of 5.7 per 1,000 for Grimsby deep sea fishermen in 1963. In a year when there was no foundering or loss of Grimsby trawlers, the fatal accident rate of Grimsby trawlermen was more than twice that of fishermen of the United Kingdom, four times the rate for miners, and 40 times that for the manufacturing industries.

The most common injuries were, in order of incidence, contusions of varying degrees of severity, infected lesions, sprains and strains, lacerations, and fractures. More than half $(56.3 \%)$ of the trawlermen were incapacitated by their injuries. The highest rates of incapacity were caused by fractures, contusions, and infected lesions. The upper limb, especially the hands and fingers, was most often affected, resulting most commonly in infected lesions. Third hands, mates, deck hands, deck trimmers, and deck learners had the highest incapacity rates due to injury. Third hands are especially at risk to injury. Most injuries and two deaths caused by casualties to boats occurred in fires aboard trawlers.

The most common illnesses suffered by trawlermen were gastrointestinal, respiratory, and skin diseases. Illness caused incapacity in $68.8 \%$ of the trawlermen affected. The greatest incapacity was due to gastrointestinal, cardiac, psychiatric, and respiratory illness, and firemen, third-hands, and cooks had the highest rates of incapacity. Of the illnesses said to be peculiar to fishermen, Dogger Bank itch and erysipeloid did not affect Grimsby trawlermen.

Unfit deep sea fishermen go to sea, even when so certified by a medical officer, thus possibly endangering themselves and other members of the crew.

The injuries which give rise to the highest morbidity and mortality in deep sea fishermen are primarily due to accidental causes. The following measures are suggested to reduce the toll on deep sea fishermen.

(1) The establishment of an occupational health service for trawlermen, with compulsory pre-employment and periodic examinations, would help to prevent unfit men going to sea and ensure that those sailing were of good health and not a liability to their fellows. The Medical Examination (Fishermen) Convention, 1959, of the International Labour Organization should be ratified by the United Kingdom.

'The material in this paper formed part of an M.D. thesis submitted to Queen's University, Belfast.

${ }^{2}$ Now Medical Officer of Health and Principal School Medical Officer, City of York. 
(2) Protective gloves of good quality should be worn. Careful attention should be given to cleaning the gloves, frequent washing of the hands, and early first-aid treatment.

(3) The warps and winch should be adequately guarded. More attention should be given by marine engineers to making trawl apparatus safer for those who have to use it.

(4) All existing vessels should be adapted as nearly as possible to meet the safety requirements of the proposed code of safety practice of the International Labour Organization, and all new vessels should comply fully with the requirements.

(5) The trawler is an unstable vessel, adding to the difficulties of handling heavy apparatus. The risk of accident is greatly increased in bad weather. Fishing in high gale-force winds should be prohibited.

(6) Most accidents occur in the man-handling of apparatus over the side of the trawler, a method which has changed little since the days of the sailing ship. The building of the conventional side trawler should be discontinued in favour of the stern trawler.

(7) Accidents on board ship should be notifiable, properly recorded, and thoroughly investigated. Safety officers should be appointed. Legislative measures should be introduced, similar to those which promote the safety of the shore worker.

(8) There should be an accident prevention campaign, with attention specially directed towards the new entrant to the industry.

The mortality and morbidity of deep sea fishermen sailing from Grimsby in 1963 have been studied. The main source of information about trawlermen is the Official Trawler Log-book. In it are recorded the length of time a trawlerman spends at sea, his age and rating, the injuries and illnesses he suffers, and the time off duty at sea due to them. Details of deaths are also entered. The actual number of mandays at sea sailed by these trawlermen can be discovered. Knowing the number of days of incapacity at sea and the number ashore (acquired from sources mentioned below), an incapacity rate by age and rating due to different injuries and illnesses can be calculated.

Grimsby trawlermen receive medical care at a special clinic (The Grimsby Exchange Clinic) provided by the trawler owners. Additional information about injury, illness, and death was, therefore, sought there. At the clinic there were also records of incapacity ashore. Where necessary, general practitioners, hospitals at home and overseas, and the Special Treatment Centre were contacted so that details of a trawlerman's malady could be completed.

Some fishermen were treated by medical officers of the Fishery Protection Squadron. Copies of their journals were acquired from the Ministry of Defence.

In many instances, there was still insufficient information so that finally permission was received from the trawlermen to examine their records with the then Ministry of Pensions and National Insurance.

A record card was made for each injured or ill trawlerman so that information from all sources could be collated.
Method

The population at risk

Difficulties of defining population When enquiries began, the writer found that it was impossible to discover the actual number of deep sea fishermen who sailed in any year, or the length of time the trawlerman spends at sea. Trawlermen change ships frequently, between different sizes of trawler and, occasionally, to other types of vessel, e.g., the seine net or inshore fishing boat. If laid off his own ship temporarily, he may take a job ashore.

Trawlermen also change their rating. For example, a skipper may sail as mate, with change of vessel, or as deck hand in other circumstances, such as loss of skill, advancing age or a reduction of the number of trawlers sailing. Older men often sail as assistant cooks (galley boys).

The vessel owners' attempt - disadvantages The Grimsby Fishing Vessel Owners' Association carried out a census by age and rating of all fishermen registered with them on February 28, 1963 (Table 1). It was commonly believed both inside and outside the fishing industry that most fishermen give up their occupation in their late thirties. As this was the first time the age distribution of Grimsby fishermen had been demonstrated, it came as a surprise to the owners that $38.8 \%$ of the 3,365 Grimsby deep sea fishermen registered at this time were over $\mathbf{4 0}$ and $5.3 \%$ were over 60 .

The number of trawlermen required to crew all the trawlers at sea out of Grimsby on February 28, 1963 was estimated by the owners to be 2,664 . On the same day, 212 were receiving unemployment benefit. The remaining 489 were assumed to be sailing in vessels other than trawlers or were in temporary jobs ashore.

A trawlerman registered under a certain rating was 
TABLE 1

Number of Trawlermen by Age and Rating Registered with the Grimsby Fishing VesSel OWNers' AsSOCiation ON February 28, 1963

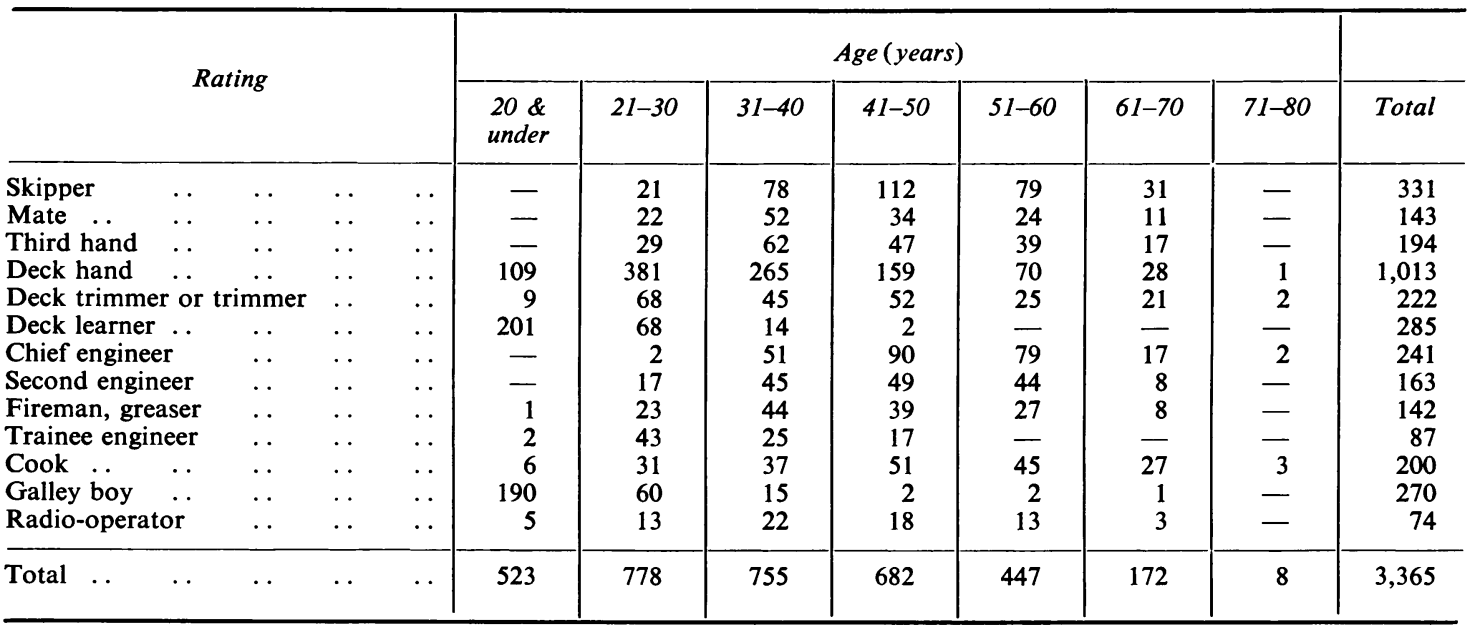

not necessarily sailing as such on February 28, 1963. A trawler carries a skipper, a mate, and a third hand, yet on that date 331 skippers, 143 mates, and 194 third hands were registered (Table 1). Some registered skippers must, therefore, have been sailing under another rating. This illustrates the inaccuracy of such a distribution table. It was a useful guide to the trawler owners but of no use as a measurement of the number of trawlermen sailing from Grimsby.

It was realized that the only accurate method of measuring the population was to count the actual number of days sailed by every trawlerman out of Grimsby in the year 1963. This information was obtained from the log-books.

Population, defined from log-book entries as man-days exposed From the 'Particulars of Engagement' in the log-book, the capacity (rating), age, and the date of 'signing on' of trawlermen were noted and, from the 'Particulars of Discharge', the date of discharge.

As the number and duration of voyages for the six months are not shown in the log-book, this information was calculated, from the dates of engagement and discharge of various trawlermen who sailed for one trip only. This was necessary as a trawlerman may sign on for more than one trip. The calculation of his time at sea from the date of engagement to the date of discharge would, therefore, include days ashore between trips. The correct duration of time at sea was arrived at by subtracting the number of days ashore from the number of days between engagement and discharge (whether at the end of a voyage or before it because of injury, illness or death), both dates inclusive.

The only known source of inaccuracy was to include the days of sailing and return in the number of days at sea. But as a trawler usually sails on the early morning tide and returns on an evening one, and tides vary daily, it is probably more accurate to include the days of sailing and return than to exclude them.
The trawlermen were classified according to age and rating and the number of man-days in each category was calculated. Each log-book contained between 14 and 109 (average about 60) entries of dates of engagement and discharge, i.e., in 288 log-books there were over 17,000 entries. From these, Table 2 was compiled and shows the number of man-days sailed by Grimsby trawlermen by age and rating in the year 1963.

In the industry it is reckoned that the trawlerman sails for an average of $\mathbf{3 0 0}$ days in any year when holidays, etc. are excluded. By dividing the number of man-days sailed in the year by 300 , one can obtain an estimate of the number of trawlermen at sea. Table 3 is the result of such a calculation and may be compared with the number of trawlermen registered (Table 1). Approximately 2,460 trawlermen were at sea in 1963 (Table 3). This compares closely with the number $(2,664)$ of trawlermen required to crew all the trawlers at sea on February 28, 1963, as determined by the trawler owners, and is just over twothirds of the number of trawlermen registered (Table 1).

By ratings, the only comparable figures between those registered and those sailing are for mates (143 registered and 149 sailing) and firemen and greasers taken together (142 registered and 137 sailing). Some show gross differences, e.g., skippers, of whom 331 were registered but only 150 sailing, deck learners (285 registered and 114 sailing), and galley boys (270 registered and 88 sailing).

By age, more were registered in each age group than sailed, and the difference was greatest for the younger age groups. Eight trawlermen aged 71-80 were registered but none sailed in 1963 .

This confirms that the use of registration figures for statistical purposes would lead to inaccurate conclusions.

\section{Sources of mortality and morbidity data}

The Official Trawler Log-book To study the epidemiology of injuries, illnesses, and deaths of deep sea 
TABLE 2

Man-days at Sea sailed by Deep Sea Fishermen out of Grimsby for the Period JANUARY TO DECEMBER, 1963

\begin{tabular}{|c|c|c|c|c|c|c|c|c|c|c|c|c|}
\hline \multirow{2}{*}{\multicolumn{6}{|c|}{ Rating }} & \multicolumn{6}{|c|}{ Age (years) } & \multirow{2}{*}{ Total } \\
\hline & & & & & & $\begin{array}{r}\begin{array}{r}20 \& \\
\text { under }\end{array} \\
26\end{array}$ & $\frac{21-30}{4.144}$ & $\begin{array}{l}31-40 \\
16,734\end{array}$ & $\frac{41-50}{16,386}$ & $\begin{array}{r}51-60 \\
7,173\end{array}$ & $\begin{array}{r}61-70 \\
578\end{array}$ & \\
\hline $\begin{array}{l}\text { Skipper } \quad . \\
\text { Mate } \\
\text { Third hand } \\
\text { Deck hand } \\
\text { Deck trimmer } \\
\text { Deck learner } \\
\text { Chief engineer } \\
\text { Second engineer } \\
\text { Fireman .. } \\
\text { Greaser .. } \\
\text { Trainee engineer } \\
\text { Cook .. } \\
\text { Galley boy } \\
\text { Radio-operator } \\
\text { Trainee radio-op }\end{array}$ & $\begin{array}{l}\ldots \\
\ldots \\
\ldots \\
\ldots \\
\ldots \\
\ldots \\
\ldots \\
\ldots \\
\ldots \\
\ldots \\
\ldots \\
\ldots \\
\ldots \\
\ldots \\
\text {. }\end{array}$ & $\begin{array}{l}\cdots \\
\cdots \\
\cdots \\
\cdots \\
\cdots \\
\cdots \\
\cdots \\
\cdots \\
\cdots \\
\cdots \\
\cdots \\
\cdots \\
\cdots \\
\cdots \\
\cdots\end{array}$ & $\begin{array}{l}. \\
\ldots \\
\ldots \\
\ldots \\
\ldots \\
\ldots \\
\ldots \\
\ldots \\
\ldots \\
\ldots \\
\ldots \\
\ldots \\
\cdots\end{array}$ & $\begin{array}{l}. \\
\cdots \\
\cdots \\
\cdots \\
\cdots \\
\ldots \\
\cdots \\
\cdots \\
\cdots \\
\ldots \\
\cdots \\
\cdots \\
\cdots \\
\cdots\end{array}$ & $\begin{array}{l}\cdots \\
\cdots \\
\cdots \\
\cdots \\
\cdots \\
\cdots \\
\cdots \\
\cdots \\
\cdots \\
\cdots \\
\cdots \\
\cdots \\
\cdots \\
\cdots \\
\cdots\end{array}$ & $\begin{array}{r}26 \\
-\quad 593 \\
48,048 \\
4,052 \\
31,069 \\
67 \\
610 \\
618 \\
19 \\
1,448 \\
1,637 \\
22,323 \\
3,006 \\
132\end{array}$ & $\begin{array}{r}4,144 \\
9,516 \\
7,173 \\
84,574 \\
13,184 \\
2,371 \\
2,795 \\
5,542 \\
3,004 \\
518 \\
3,719 \\
6,677 \\
2,261 \\
6,323 \\
75\end{array}$ & $\begin{array}{r}16,734 \\
18,184 \\
16,457 \\
64,409 \\
10,339 \\
580 \\
11,414 \\
9,706 \\
10,675 \\
1,659 \\
7,161 \\
6,333 \\
669 \\
7,312 \\
-\end{array}$ & $\begin{array}{r}16,386 \\
13,619 \\
13,099 \\
50,876 \\
11,838 \\
283 \\
21,534 \\
13,522 \\
12,728 \\
3,152 \\
5,824 \\
14,922 \\
868 \\
6,026 \\
-\end{array}$ & $\begin{array}{r}7,173 \\
3,376 \\
6,719 \\
30,378 \\
4,227 \\
14 \\
8,450 \\
7,369 \\
7,560 \\
376 \\
1,932 \\
10,836 \\
138 \\
2,897 \\
-\end{array}$ & $\begin{array}{r}578 \\
178 \\
110 \\
6,927 \\
172 \\
- \\
566 \\
728 \\
389 \\
299 \\
239 \\
4,009 \\
70 \\
524 \\
-\end{array}$ & $\begin{array}{r}45,041 \\
44,873 \\
44,151 \\
285,212 \\
43,812 \\
34,317 \\
44,826 \\
37,477 \\
34,974 \\
6,023 \\
20,323 \\
44,414 \\
26,329 \\
26,088 \\
207\end{array}$ \\
\hline Total & . & .. & - & $\cdots$ & .. & 113,648 & 151,876 & 181,632 & 184,677 & 91,445 & 14,789 & 738,067 \\
\hline Percentage & . & . & . & . & . & $15 \cdot 4$ & $20 \cdot 6$ & $24 \cdot 6$ & $25 \cdot 0$ & $12 \cdot 4$ & $2 \cdot 0$ & 100 \\
\hline Supernumerary & $\begin{array}{c}\text { Man- } \\
. .\end{array}$ & .. & . & . & $\begin{array}{c}\text { nerar } \\
. .\end{array}$ & $\begin{array}{l}\text { (not inc } \\
2,963^{1}\end{array}$ & $\begin{array}{c}\text { ded in the } \\
788\end{array}$ & total man & $\begin{array}{c}\text { zys sailed } \\
240\end{array}$ & $\begin{array}{c}\text { by trawle } \\
136\end{array}$ & n) 24 & 4,786 \\
\hline
\end{tabular}

${ }^{1}$ Included are 62 man-days at sea sailed by supernumeraries aged 10 years old and under.

TABLE 3

Approximate Number of Deep Sea Fishermen sailing from Grimsby in 1963 (from Table 2,

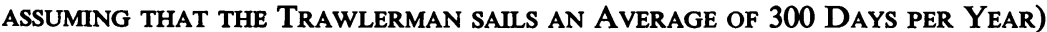

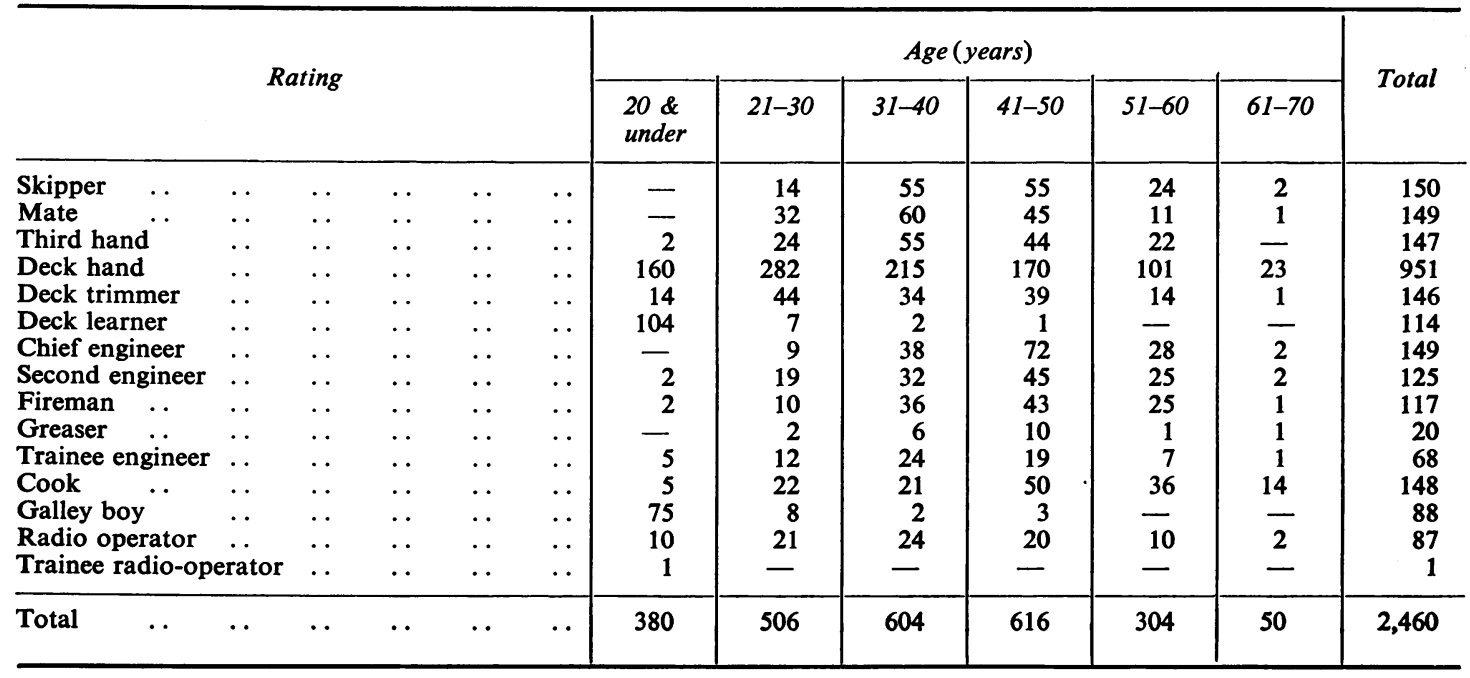


fishermen, special permission was gained from the Ministry of Transport (now the Board of Trade) to examine the Official Log-books of all the trawlers that sailed from Grimsby in the year 1963. Two hundred and eighty-eight were examined in which were recorded 778 incidents of injury, illness, and death.

The Merchant Shipping Act, 1894, Section 385, requires that "the skipper of a fishing boat shall keep a record . . . of every death or injury of any member of his boat's crew while at sea, or any person on board his boat', in the Official Trawler Log-book, under the following headings: Date of Death; Place of Death; Name and Surname of Deceased; Sex; Age; Rank or Rating; Profession or Occupation; Nationality, stating Birthplace; Last Place of Abode; Cause of Death; Signature of Skipper or Person in Charge; and Signature of some Member of the Crew.

The 'Record of Injuries or Illnesses not Resulting in Death' is also in the log-book under the following headings: Date; Place of Occurrence; Name and Surname of Person Injured or Sick; Sex; Age; Capacity; Number of Days off Duty; Nature and Cause of Injury or Illness; Signature of Skipper or Person in Charge; and Signature of some Member of the Crew.

The Registrar General of Shipping and Seamen In accordance with Section 254 of the Merchant Shipping Act, 1894, deaths occurring aboard ship must be reported to the Registrar General of Shipping and Seamen.

When a death at sea is presumed by the skipper to have taken place because the deceased is reported to be 'missing', or where a person is supposed killed or drowned as a result of falling or jumping overboard, falling from a rope ladder attached to the ship or from the ship's gangway, it should be regarded as having taken place on board. Deaths which occur otherwise than on board should not be so recorded but full particulars of the circumstances of such deaths, if known, should be recorded in the narrative section of the Official Log-book. The skipper also completes a 'Return of Births and Deaths occurring on Board' (Form B \& D1) in the former circumstances and a 'Return of Death of a Merchant Seaman or Fisherman occurring otherwise than on Board a Ship' (Form B \& D2) in the latter. The forms are forwarded to the Registrar General of Shipping and Seamen, Llandaff, Cardiff, who compiles a monthly report of Deaths of Merchant Seamen and Fishermen Reported to the Registrar General of Shipping and Seamen for the particular month (Form G.R. 160, New Series).

The Registrar General of Shipping and Seamen supplied information about certain of the Grimsby trawlermen who died in 1963.

The medical records of the Grimsby Exchange Clinic The Grimsby Fishing Vessels Owners' Association provides medical care for trawler crews at the Grimsby Exchange Clinic and medical records of fishermen are kept there. In addition, there are certain details of the treatment received by fishermen overseas, e.g., as relayed from overseas by radio.

The log-book entries were checked against the records at the clinic and details of the treatment of 422 of the 778 logged incidents were available. There were also records of 59 other incidents which occurred at sea for which fishermen attended the clinic for treatment, but which were not logged by the trawler skippers. These are included in the following analysis, making a total of 837 incidents.

Grimsby fishermen contribute to the Grimsby Trawler and Seine-net Crews' Personal Contributory Accident and Life Assurance Scheme (for convenience called the Fishermen's Insurance Scheme). It is a requirement of the scheme that they attend the clinic for certification of incapacity to qualify for benefit. A record of the number of days of benefit received for injury is kept and the number of days' absence from sea due to injury was therefore noted from the Grimsby Exchange Clinic records.

The hospitals, at home and overseas Where necessary, further information was acquired from the records of three Grimsby hospitals, and the area mental hospital at Lincoln. Six hospitals in the United Kingdom (other than Grimsby and Lincoln) and 22 overseas were also contacted and replies were received from all six of the former and from 11 of the latter. Enquiries were made about 18 fishermen treated in the United Kingdom (other than Grimsby and Lincoln) and 140 treated overseas, and replies were received about 14 of the former and 32 of the latter.

The Special Treatment Centre, Grimsby Records were examined of five fishermen who were logged as suffering from venereal disease in 1963.

General practitioners Where necessary, additional information was acquired from the fisherman's general practitioner. However, in many cases the practitioner was not known. In all, 19 general practitioners in the Grimsby area were contacted about their fishermen patients.

The Royal Navy Information was received from the Medical Director General (Naval) of the Ministry of Defence regarding medical aid, given to 27 Grimsby fishermen with logged injuries and illnesses in 1963, by medical officers of the Fishery Protection Squadron vessels of the Icelandic patrol. Additional information was received about 29 Grimsby fishermen who were treated for injuries and illnesses which were not logged, and about 64 non-Grimsby fishermen. The 29 non-logged injuries and illnesses are not included in the total number analysed as there were no details as to age and rating. The total number of injuries and illnesses, and their nature, of all the fishermen treated by medical officers of the Fishery Protection Squadron are shown in Table 4.

The Ministry of Pensions and National Insurance In most cases, information about injuries was available from the sources described above. However, details of illnesses were more difficult to find, especially the number of days' incapacity suffered by individual fishermen. The Ministry of Pensions and National Insurance (now the Ministry of Social Security) had medical records and details of incapacity. However, this information could only be divulged if a written consent from each fisherman to examine his records was forwarded to the Regional Office of the Ministry. 
TABLE 4

INJURIES AND ILLNESSES OF ALL FISHERMEN (INCLUDING NON-GRIMSBY FISHERMEN) TREATED BY H.M. SHIPS IN 1963

\begin{tabular}{|c|c|c|c|c|c|}
\hline Injury & & No. & Illness & & No. \\
\hline $\begin{array}{l}\text { Contusion } \quad . . \\
\text { Fracture } \quad . \\
\text { Infected trauma } \\
\text { Laceration . } \\
\text { Sprain and strain } \\
\text { Amputation ... } \\
\text { Eye injury a. } \\
\text { Burn and scald }\end{array}$ & $\begin{array}{l}\ldots \\
\cdots \\
\cdots \\
\cdots \\
\cdots \\
\cdots \\
\cdots\end{array}$ & $\begin{array}{c}20 \\
8^{1} \\
7 \\
6 \\
5 \\
2 \\
2 \\
2\end{array}$ & 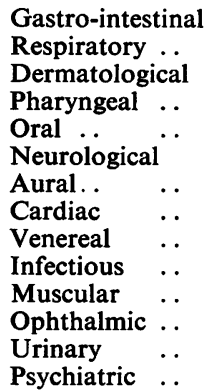 & $\begin{array}{l}\ldots \\
\cdots \\
\cdots \\
\cdots \\
\cdots \\
\cdots \\
\cdots \\
\cdots \\
\cdots \\
\cdots \\
\cdots \\
\cdots \\
\cdots\end{array}$ & $\begin{array}{l}15 \\
10 \\
10 \\
7 \\
5 \\
4 \\
3 \\
3^{2} \\
3 \\
3 \\
2 \\
1 \\
1 \\
1\end{array}$ \\
\hline Cotal .. & & 52 & & & 68 \\
\hline
\end{tabular}

${ }^{1}$ Includes one dislocation of finger and a death due to fracture of the skull.

${ }^{2}$ Two illnesses terminated in death.

As men are difficult to contact during their few hours ashore, it was thought advisable to write to fishermen in the first instance and to follow up those who did not answer by a personal approach at their homes. A letter was sent to $87(75 \%)$ of the 116 fishermen who had suffered illness and a consent slip was returned by 35 $(30.1 \%)$ fishermen. The remainder (52) were therefore followed up, the more resistant ones requiring persistent personal calls over a period of about three months. Twenty-one fishermen could not be traced and 31 replies were received as a result of personal approach.
Of the total of 66 replies, permission to examine their records was given by 46 fishermen and the mother of a fisherman who had died $(71.2 \%)$ and refused by 19 $(28.8 \%)$. The consent slips were forwarded to the Regional Office of the Ministry of Pensions and National Insurance and information was returned by the Area Manager, Grimsby.

\section{Calculation of rates}

In order to measure the morbidity due to injury and illness, and to compare the morbidity resulting from different injuries, and that due to injury and illness in the various ratings and age groups, an incapacity rate has been calculated. The number of man-days of incapacity at sea and/or ashore due to injury or illness was calculated. The incapacity rate was calculated by dividing the number of man-days lost through injury or illness by the number of man-days at sea for that particular age and rating of trawlermen (Table 2), and multiplying by 1,000 , giving a rate per 1,000 man-days at sea.

The known number of days of incapacity at sea, at sea and ashore, or ashore due to injury or illness which occurred at sea, has been calculated for every trawlerman off work.

\section{Mortality}

Fourteen Grimsby trawlermen died in the year 1963 from injury or illness which occurred at sea, eight due to natural causes and six due to accidental causes. Particulars of these deaths are shown in Table 5, with the sources of information.

\section{Accidental causes of death}

Six deaths were due to accidental causes.

Drowning Two trawlermen, the mate of a stern trawler and a deck hand of a conventional trawler,

TABLE 5

Causes of Death showing Age and Rating of Trawlermen, Place of Death and Source of INFORMATION

\begin{tabular}{|c|c|c|c|c|}
\hline Cause of death & Rating & Age & Place of death & Source of information as to cause of death \\
\hline \multicolumn{5}{|l|}{ Accidental } \\
\hline Drowning & Mate & 56 & North Sea & Registrar General of Shipping and Seamen \\
\hline Drowning & Deck trimmer & 30 & White Sea & Registrar General of Shipping and Seamen \\
\hline Supposed drowning .. & Deck hand & 38 & West Iceland & Registrar General of Shipping and Seamen \\
\hline Presumed suffocation & Second engineer & 42 & Trawler & Registrar General of Shipping and Seamen \\
\hline Presumed suffocation & Greaser & 27 & Trawler & Registrar General of Shipping and Seamen \\
\hline Head injuries & Deck hand & 28 & Trawler & Registrar General of Shipping and Seamen \\
\hline \multicolumn{5}{|l|}{ Natural } \\
\hline Heart attack & Deck hand & 55 & Kristiansund & Official Trawler Log-book \\
\hline Acute left ventricular failure & Third hand & 56 & Trawler & Coroner's inquest following necropsy \\
\hline Myocardial fibrosis ... & Deck hand & 44 & Trawler & Registrar General of Shipping and Seamen \\
\hline Coronary thrombosis & Deck hand & 58 & Trawler & Certified cause of death \\
\hline Coronary artery occlusion .. & Cook & 64 & $\begin{array}{c}\text { Helicopter off } \\
\text { Bridlington }\end{array}$ & Coroner after necropsy without inquest \\
\hline Subarachnoid haemorrhage. . & Galley boy & 18 & Trawler & Necropsy \\
\hline Bronchial carcinoma $\quad \ldots$ & Fireman & 46 & Glasgow & Certified cause of death \\
\hline Appendicitis and peritonitis. . & Mate & 46 & Siglufjord & Registrar General of Shipping and Seamen \\
\hline
\end{tabular}


were pulled overboard by the fishing gear. A third, a deck trimmer, was reported missing, the cause of his disappearance being unknown, and a search of the area ensued. His body was not recovered until two days later when it was picked up by another trawler. Of the deaths due to drowning, two occurred in good weather, one in daytime and the other at night.

Presumed suffocation A second engineer and a greaser died in their cabins when there was an outbreak of fire.

Head injuries When struck by a Gilson hook (part of the lifting gear), a deck hand fell, hitting his head on a deck stanchion.

\section{Natural causes of death}

Eight deaths were due to natural causes. Five trawlermen died of cardiac disease, and one each of vascular disease of the central nervous system, respiratory disease, and disease of the digestive system.

Cardiac disease 'Natural causes' were recorded by the Registrar General for two trawlermen, a deck hand who had a 'heart attack' and was landed at Kristiansund where he died 19 days later, and another who died on board in Grimsby docks and whose death was certified as due to coronary thrombosis.

A third hand, who collapsed and died as the trawl was being shot, was landed at Grimsby some hours later. The cause of death was 'suspected coronary thrombosis' (Registrar General of Shipping and Seamen). Personal communication with the Registrar General showed that the trawlerman 'was the subject of a Coroner's Inquest and a postmortem examination revealed the cause of death as acute left ventricular failure, hypertension (essential), natural causes'.

Other causes The logged illness of a galley boy, who complained of stomach trouble and was put ashore at Honningsvag, was 'a possible appendix'. Personal communication with the hospital showed that, on admission, he had an acute abdomen. Discharged two days later and taken on board another trawler for the return passage home, he was later found dead in his bunk. Post-mortem examination showed that the cause of death was 'idiopathic subarachnoid haemorrhage'.

Because of pains in the head, a fireman was landed at Akureyri. He was diagnosed as suffering from bronchial carcinoma with cerebral metastasis and flown to Reykjavik five days after admission and from there to Glasgow where he died five days later.

Having complained of pains in the stomach, a mate was landed at Siglufjord. The hospital records showed that this trawlerman, who was admitted following an illness of three days at sea, had a diffuse peritonitis and was treated with antibiotics, parenteral fluid, and duodenal drainage but died 13 days later.

Mortality rate due to injury or illness which began at sea

The total number of man-days at sea was 738,067 . Reckoning that the trawlerman averages 300 days at sea, the estimated number of trawlermen sailing in the year was 2,460 . Using this figure as the population at risk, the mortality rate for Grimsby trawlermen in 1963 was 5.7 per $1,000(2.4$ per 1,000 due to accidental causes and $3 \cdot 3$ due to natural causes).

\section{Morbidity}

Morbidity in fishermen who had more than one injury or illness in 1963

In the survey of all the injuries, illnesses, and deaths of deep sea fishermen who sailed from Grimsby in 1963, 837 incidents were investigated (Table 6).

\section{TABLE 6}

Grimsby DeEP SEA Fishermen 1963 : NUMBer AND NATURE OF INCIDENTS INVESTIGATED IN A SURVEY OF THE INJURIES, ILLNESSES, AND DeATHS

\begin{tabular}{|c|c|c|c|}
\hline \multicolumn{3}{|c|}{ Nature of incident } & \multirow{2}{*}{$\begin{array}{c}\text { No. of } \\
\text { incidents }\end{array}$} \\
\hline $\begin{array}{l}\text { Injury (at sea) } \\
\text { Injury (ashore) } \\
\text { Illness . . } \\
\text { Not specified } \\
\text { Deaths . . }\end{array}$ & $\begin{array}{l}\cdots \\
\cdots \\
\cdots \\
\cdots\end{array}$ & $\begin{array}{l}\cdots \\
\cdots \\
\cdots \\
\cdots\end{array}$ & \\
\hline Total & $\ldots$ & . & 837 \\
\hline
\end{tabular}

Multiple incidents of injury, illness, and death were recorded for 91 fishermen, one of whom was involved in five incidents, eight in three, and 82 in two incidents.

\section{Morbidity due to injury at sea}

Grimsby trawlermen in 1963 suffered 693 injuries (Table 7) of which more than one-third were contusions, the next most common being infected traumata, followed by sprains and strains.

Nature of lesions The descriptions of lesions in the log-books were very brief and were often covered by one word, e.g., bruise, cut or prick. The extent of an injury was occasionally described, but also 
TABLE 7

Number, Nature, and Stre of InJURy EXPERIEnCEd by Grimsby Deep Sea Fishermen IN 1963 IN ORDER OF INCIDENCE

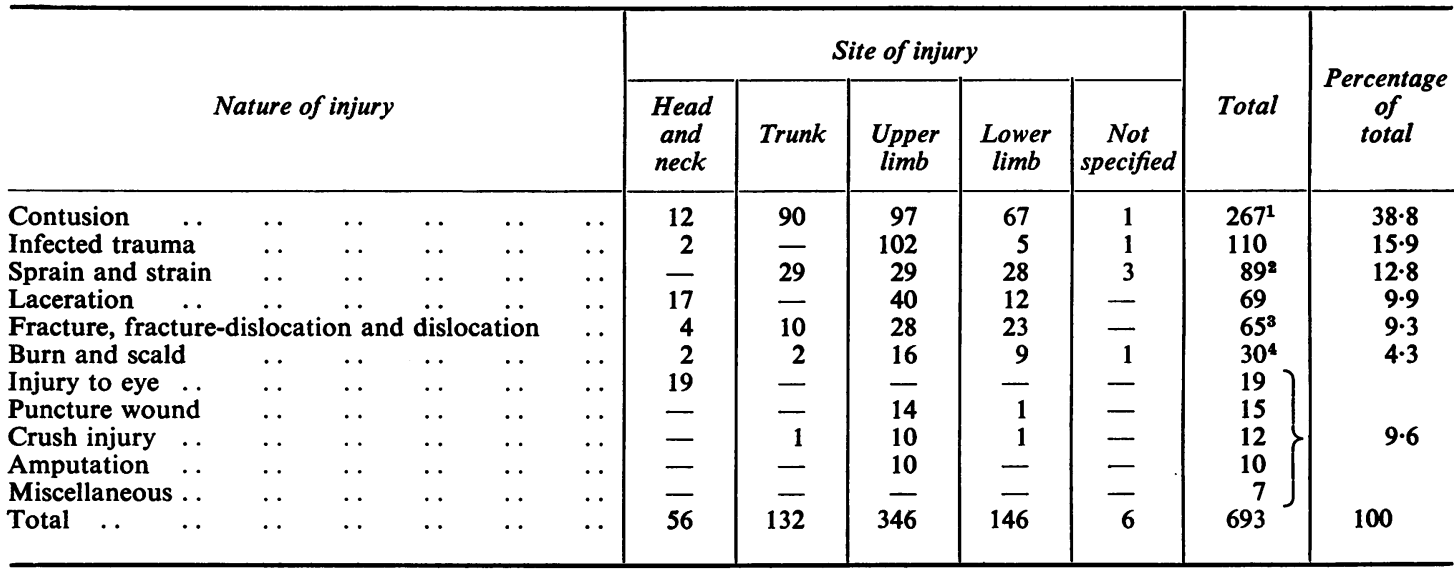

${ }^{1}$ Includes loss of consciousness due to injury on three occasions.

247 sprains and 42 strains, includes internal derangement of nine joints and the recurrence of two old injuries.

358 fractures, three dislocations and four fracture-dislocations, and includes two instances of loss of consciousness.

${ }^{4}$ Eight burns and 22 scalds.

briefly, e.g., 'a cut 2 in. long'. The skipper sometimes quoted a description given by a doctor who had treated an injury overseas, and only then was additional information given.

The records of injury from medical sources were on the whole disappointing, those from hospital out-patient departments being probably the worst example of medical recording. Consequently, little detail of the nature of the lesion can be given in the following account of the types of injury experienced by trawlermen.

Contusions Over a third of the injuries $(38.3 \%)$ were contusions of varying degrees of severity. In injuries logged as bruises, large areas of skin and subcutaneous tissues were damaged. For example, 'Extensive bruising of the right hamstring group of muscles with tenderness and swelling' was noted some days after a deck learner had fallen from a winch against a deck stanchion. The abdominal wall of a third hand, knocked unconscious when the cod-end laden with fish fell on him, showed extensive bruising. Given two morphia injections by the skipper, he was landed at Tromsö for treatment. Two other trawlermen were rendered unconscious by injuries described as contusions.

Forty trawlermen sustained bruising of the chest wall.

Assistance was given on two occasions by medical officers of the Fishery Protection Squadron, and 23 fishermen were put ashore for treatment.

The less severe type of bruising usually seen ashore would be considered trivial by the trawlerman and is unlikely to be logged by or even reported to the skipper.

Infected trauma In 110 trawlermen who were injured, the wounds became infected, amounting to $15.9 \%$ of the total injuries. This was the second most common type of injury recorded. Thirty-two trawlermen had paronychia and 10 had infected lacerations. There were four pulp and four palmar space infections. Ten infected injuries were incised, one of which was 'lanced' by the skipper. Culture of the pus from four injuries showed that the infection was due to Staphylococcus pyogenes, and five injuries were treated by the skipper with penicillin tablets.

Two trawlermen received treatment by medical officers of the Fishery Protection Squadron and eight were landed for treatment overseas.

Sprain and strain Joint sprains and muscular strains were the third most common group of injuries. There were 89 such injuries, 47 of which were sprains and 42 strains, being $12.8 \%$ of the total injuries. Eight of the sprains which involved the knee joint were diagnosed, on medical examination, as internal derangement of the joint.

A second engineer who fell into a fish room, straining his back and injuring his hand, was taken ashore unconscious at Grimsby and was in hospital for seven days. A third hand seen by a medical officer of the Fishery Protection Squadron two days 
after straining his back by pulling on the net was still 'rigid and tender'. After falling down steps, a galley boy was taken ashore with a 'sprained knee'. This boy had a haemarthrosis which required hospital treatment.

Treatment was given on three occasions by the Fishery Protection Squadron doctors, and trawlermen were put ashore on 12 occasions.

Laceration Laceration $(9.9 \%)$ was the fourth most common type of injury.

The size of a laceration was described on only three occasions. For example, a deck hand was struck on the head by the after trawl door, which caused a laceration $2 \frac{1}{2}-3$ in. long. Taken off the trawler by H.M. Ship, he was put ashore for hospital treatment at Reykjavik. When seen at the Grimsby Exchange Clinic, the wound was 'infected and gaping'. Again, two trawlermen lost consciousness, one when he fell down the cabin steps, lacerating his scalp, and the other when knocked down by heavy seas, lacerating his right eyebrow, which required five sutures when he was landed at Thingeyri.

Four trawlermen with lacerations received aid from medical officers of the Fishery Protection Squadron, and 15 were put ashore for treatment. A further 13 trawlermen had infected lacerations (infected traumata), i.e., of a total of 82 lacerations, $15.8 \%$ became infected.

Fracture, fracture-dislocation, and dislocation Fracture, fracture-dislocation and dislocation $(9.3 \%)$ formed the fifth largest group of injuries. The upper limb was involved on 28 occasions and the lower on 23. There were 10 fractures of ribs.

Fractures of the humerus, radius, and ulna occurred when a deck hand aged 18 had his left arm trapped between the trawl door and the gallows. As a result he become permanently unfit for sea. Two head injuries caused fractures of the skull and unconsciousness. Two trawlermen had complications from fractured ribs, a pneumothorax and haemothorax, and an exacerbation of a previous chest complaint, respectively.

Medical aid was given by medical officers of the Fishery Protection Squadron on five occasions and a dislocation was reduced on board one of H.M. Ships. Twenty-nine trawlermen with these injuries were put ashore for treatment.

Puncture wound The puncture wound which the trawlerman suffers is a small lesion which he calls a prick or, more specifically when the cause is known, a wire prick or fish bone prick. Fifteen trawlermen $(2 \cdot 2 \%)$ were logged as having pricks, none of which caused incapacity. However, infection of the hands and fingers, etc. (infected trauma) was caused by pricks in 66 fishermen. Of a total of 81 puncture wounds, $81.4 \%$ became infected, and infected puncture wounds comprised $60.5 \%$ of the infected traumata, causing, for example, paronychia, pulp and palmar space infections, and cellulitis.

Crush injury Twelve (1.7\%) injuries were described in the $\log$ as crush injuries. The nature of the injury was not described. Ten were of the fingers and there was one each of the chest and foot. The crush injury to the chest occurred when a third hand was trapped between a warp and the ship's side by the full weight of the trawl. He had a chest radiograph for fracture of the ribs, which showed no damage to bone. Four trawlermen were put ashore for treatment.

Amputation All the amputations were of fingers. Of the $10(1.4 \%)$, seven were traumatic and three surgical.

A deck hand who had both hands trapped between the warp and the ship's side lost his right index finger. Another, struck by the towing block, had his left little finger amputated. One trawlerman had his injury treated aboard a German hospital ship and five were put ashore for treatment.

Site of lesion Just under half $(49.8 \%)$ of the injuries involved the upper limb, the most common being infected trauma. Over two-thirds of these injuries were to the hands and fingers (Table 7). One-fifth of the injuries (21\%) involved the lower limb, the knee being injured most often in just over one quarter of the injuries.

Cause of injury As recorded in the Official Logbook, there were six principal ways in which injury

TABLE 8

Grimsby Deep Sea Fishermen 1963: NATURe and Cause of INJURIes

\begin{tabular}{cc|c|c|c|c|c|c|c|c|c}
\hline & & \multicolumn{8}{c|}{ Cause of injury } & \\
\cline { 2 - 10 } & & Fature of injury & Slip & Trapped & Blow & $\begin{array}{c}\text { Falling } \\
\text { object }\end{array}$ & $\begin{array}{c}\text { Knocked } \\
\text { down by } \\
\text { sea }\end{array}$ & Miscellaneous & $\begin{array}{c}\text { Not } \\
\text { specified }\end{array}$ & Total \\
\hline Total &.. & 124 & 77 & 101 & 72 & 27 & 34 & 204 & 54 & 693 \\
\hline
\end{tabular}


TABLE 9

Grimsby Deep Sea Fishermen 1963: Number of Spells and Days of Incapacity at Sea, at Sea aND Ashore, AND Ashore due to InJURy, Frostbite, AsphyXIA, AND Electric SHOCK

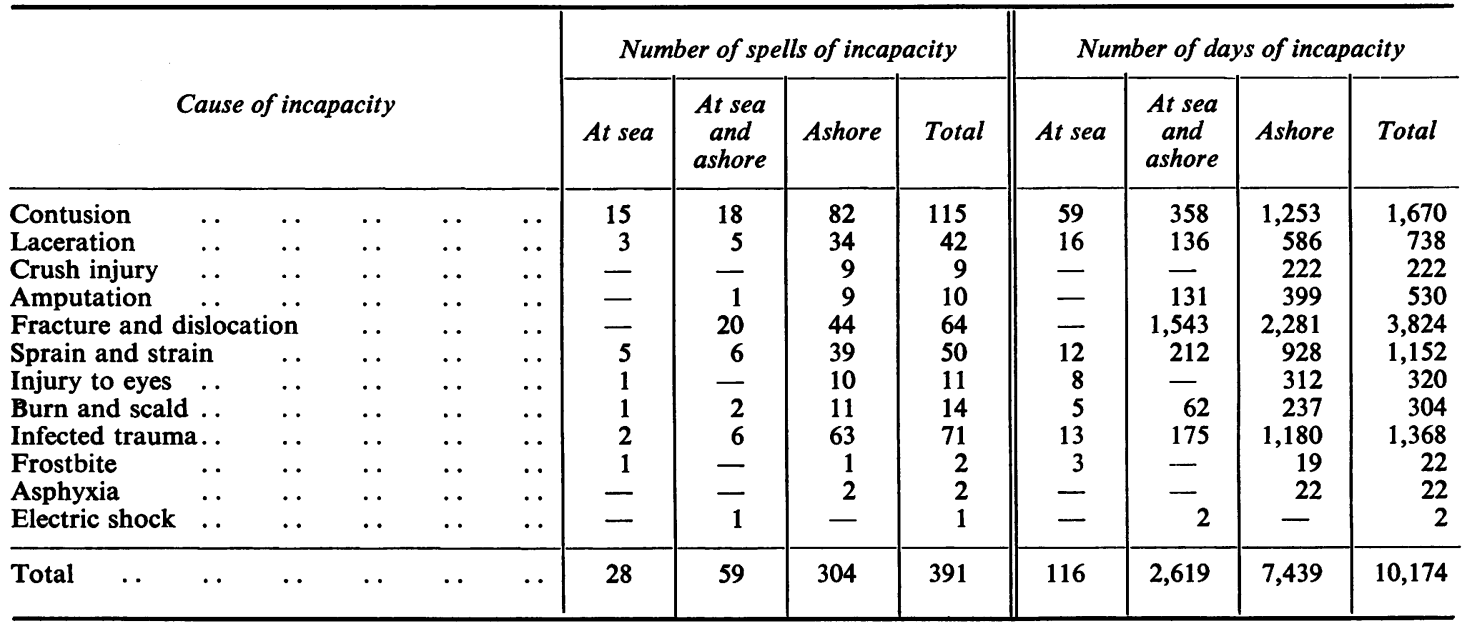

to trawlermen occurred. These (and their incidence) are given in Table 8.

Falls were the most common cause of injury, $56(45.2 \%)$ of which occurred on deck and nine when the trawlerman fell against the winch. Falls and falls following slipping together caused 201 injuries or $29 \%$ of the total injuries.

Trapping accidents were the second most common cause of injury and caused all the crush injuries. Most injuries due to trapping were caused by trawl

TABLE 10

Grimsby Deep Sea Fishermen 1963: Number of Days of INCAPACITy and InCAPACITy Rates ${ }^{1}$ Per 1,000 MAN-DAYS at Sea due to InJury, Frostbite, Asphyxia, and Electric Shock showing the Trawlerman's Rating

\begin{tabular}{|c|c|c|c|c|c|c|c|c|c|c|c|c|c|}
\hline \multirow[b]{2}{*}{ Rating } & \multicolumn{12}{|c|}{ Cause of incapacity } & \multirow{2}{*}{$\underset{\text { injuries }}{\text { All }}$} \\
\hline & Contusion & $\begin{array}{c}\text { Lacera- } \\
\text { tion }\end{array}$ & $\begin{array}{l}\text { Crush } \\
\text { injury }\end{array}$ & $\begin{array}{c}\text { Amputa- } \\
\text { tion }\end{array}$ & $\begin{array}{c}\text { Fracture, } \\
\text { etc. }\end{array}$ & $\begin{array}{l}\text { Sprain } \\
\text { and } \\
\text { strain }\end{array}$ & $\begin{array}{c}\text { Injury to } \\
\text { eyes }\end{array}$ & $\begin{array}{c}\text { Burn } \\
\text { and } \\
\text { scald }\end{array}$ & $\begin{array}{l}\text { Infected } \\
\text { trauma }\end{array}$ & $\begin{array}{l}\text { Frost- } \\
\text { bite }\end{array}$ & Asphyxia & $\begin{array}{c}\text { Electric } \\
\text { shock }\end{array}$ & \\
\hline $\begin{array}{l}\text { Skipper } \\
\text { Mate } \\
\text { Third }\end{array}$ & $\overline{146(4 \cdot 6)}$ & $2 \overline{(0 \cdot 6)}$ & - & $\begin{array}{l}49(1 \cdot 1) \\
23(0 \cdot 5)\end{array}$ & $\begin{array}{r}58(1 \cdot 3) \\
470(10 \cdot 5)\end{array}$ & $\begin{array}{l}16(0 \cdot 4) \\
57(1 \cdot 3)\end{array}$ & $\begin{array}{l}10(0.2) \\
21(0.4)\end{array}$ & - & $\overline{83}(1 \cdot 8)$ & - & - & - & $\begin{array}{l}133(2 \cdot 9) \\
826(18 \cdot 4)\end{array}$ \\
\hline $\begin{array}{l}\text { hand } \\
\text { Deck }\end{array}$ & $207(4 \cdot 7)$ & $36(0 \cdot 8)$ & $28(0 \cdot 6)$ & - & $327(7 \cdot 4)$ & $184(4 \cdot 2)$ & - & $17(0 \cdot 4)$ & $174(3 \cdot 9)$ & - & - & - & $973(22 \cdot 0)$ \\
\hline $\begin{array}{l}\text { hand } \\
\text { Deck }\end{array}$ & $935(3 \cdot 3)$ & $385(1 \cdot 3)$ & $188(0 \cdot 7)$ & $327(1 \cdot 1)$ & $1,644 \quad(5 \cdot 7)$ & $650(2 \cdot 2)$ & $272(0.9)$ & $35(0 \cdot 1)$ & $581(2 \cdot 0)$ & $22(0 \cdot 1)$ & $15(0 \cdot 1)$ & - & $5,054(17 \cdot 7)$ \\
\hline $\begin{array}{l}\text { trimmer } \\
\text { Deck }\end{array}$ & $90(2 \cdot 1)$ & $7(0 \cdot 1)$ & - & - & $528(12 \cdot 1)$ & $36(0 \cdot 8)$ & $6(0 \cdot 1)$ & - & $69(1 \cdot 5)$ & - & 一 & - & $736(16 \cdot 8)$ \\
\hline $\begin{array}{l}\text { learner } \\
\text { Chief }\end{array}$ & $9(0 \cdot 3)$ & $110(3 \cdot 2)$ & $6(0 \cdot 2)$ & $63(1 \cdot 8)$ & $148 \quad(4 \cdot 3)$ & $25(0 \cdot 7)$ & $5(0 \cdot 1)$ & - & $123(3 \cdot 5)$ & - & - & - & $489(14 \cdot 2)$ \\
\hline $\begin{array}{l}\text { engineer } \\
\text { Second }\end{array}$ & $65(1 \cdot 5)$ & $10(0 \cdot 2)$ & - & - & $342(7 \cdot 6)$ & $13(0 \cdot 3)$ & - & - & $28(0 \cdot 6)$ & - & - & $2(0 \cdot 0)$ & $460(10 \cdot 3)$ \\
\hline engineer & $33(0.9)$ & $35(0.9)$ & 一 & $68 \overline{(1.0)}$ & $43(1 \cdot 1)$ & $62(1 \cdot 6)$ & 一 & - & $\overline{104}(0.9)$ & - & - & - & $173(4 \cdot 6)$ \\
\hline $\begin{array}{l}\text { Fireman } \\
\text { Greaser }\end{array}$ & $50(1 \cdot 4)$ & $9(0 \cdot 3)$ & 一 & $68(1 \cdot 9)$ & $84(2 \cdot 4)$ & - & - & - & $104(2 \cdot 9)$ & - & - & - & $315(9 \cdot 0)$ \\
\hline $\begin{array}{l}\text { Greaser } \\
\text { Trainee }\end{array}$ & & $27(4 \cdot 5)$ & - & - & - & - & - & - & 一 & - & - & - & $27(4 \cdot 5)$ \\
\hline engineer & $42(2 \cdot 1)$ & $14(0 \cdot 7)$ & 一 & - & - & - & - & $\overline{-}$ & - & - & $\overline{0}$ & - & $56(2 \cdot 7)$ \\
\hline $\begin{array}{l}\text { Cook } \\
\text { Galley boy }\end{array}$ & $93(2 \cdot 1)$ & $\begin{array}{r}71(1 \cdot 8) \\
8(0 \cdot 3)\end{array}$ & 二 & 二 & $\begin{array}{ll}90 & (2 \cdot 0) \\
69 & (2 \cdot 6)\end{array}$ & $\begin{array}{l}19(0.4) \\
58(2 \cdot 2)\end{array}$ & $6 \overline{(0 \cdot 2)}$ & $\begin{array}{r}223(5 \cdot 0) \\
29(1 \cdot 1)\end{array}$ & $\begin{array}{r}86(1.9) \\
120(4 \cdot 5)\end{array}$ & - & $7(0 \cdot 2)$ & $\overline{-}$ & $\begin{array}{l}589(13 \cdot 3) \\
290(11 \cdot 0)\end{array}$ \\
\hline $\begin{array}{l}\text { Radio- } \\
\text { operator }\end{array}$ & - & - & - & - & $21(0.8)$ & $32(1 \cdot 2)$ & - & - & - & - & - & - & $53(2.0)$ \\
\hline All ratings & $1,670(2 \cdot 3)$ & $738(1 \cdot 0)$ & $222(0 \cdot 3)$ & $530(0 \cdot 7)$ & $3,824 \quad(5 \cdot 1)$ & $1,152(1 \cdot 5)$ & $320(0.4)$ & $304(0.4)$ & $1,368(1 \cdot 8)$ & $22(0 \cdot 0)$ & $22(0 \cdot 0)$ & $2(0 \cdot 0)$ & $10,174(13 \cdot 8)$ \\
\hline
\end{tabular}


doors (17) followed by the warps and doors (15 each).

Blows from warps and the messenger wire caused $22(30.5 \%)$ injuries, on four occasions when the warp parted. Eight of the 10 amputations were due to trapping accidents, four by trapping between the warp and the ship's rail, the gallows, the winch drum, and the winch respectively, and three were due to the trapping of fingers in doors.

Thirty-four injuries occurred when trawlermen were knocked down by heavy seas. One-fifth of these resulted in fractures and one in $10(10.7 \%)$ of trawlermen who suffered fractures were knocked down by heavy seas. Most lacerations $(21.7 \%)$ were caused by knife wounds, all of which involved the upper limb.
Number of spells and days of incapacity There were 391 spells and 10,174 days of incapacity due to injury (Table 9). The average length of a spell of incapacity was 26 days. The average length of a spell of incapacity due to injury at sea was 4 days at sea, 8.6 days at sea and ashore, and 19 days ashore respectively.

The number of days of incapacity by rating are shown in Table 10. Most days of incapacity were caused by fractures and dislocations $(37.5 \%)$, contusions $(16.4 \%)$, infected traumata $(13.4 \%)$, and sprains and strains $(11 \cdot 3 \%)$.

Rates of incapacity The rate of incapacity due to injury of all trawlermen was 13.8 per 1,000 man-days

TABLE 11

Grimsby Deep Sea Fishermen 1963: Rate of InCAPACITy due to all InJURIes, Frostbite, AsphyXIA, and Electric SHOCK by Age and Rating

\begin{tabular}{|c|c|c|c|c|c|c|c|c|c|c|c|c|c|}
\hline \multirow{2}{*}{\multicolumn{7}{|c|}{ Rating of trawlerman }} & \multicolumn{6}{|c|}{ Age of trawlerman } & \multirow{2}{*}{$\begin{array}{c}\text { All } \\
\text { ages }\end{array}$} \\
\hline & & & & & & & $11-20$ & $21-30$ & $31-40$ & $41-50$ & $51-60$ & $61-70$ & \\
\hline $\begin{array}{l}\text { Skipper } \quad . \\
\text { Mate } \ldots \\
\text { Third hand .. } \\
\text { Deck hand .. } \\
\text { Deck trimmer } \\
\text { Deck learner } \\
\text { Chief engineer } \\
\text { Second engineer } \\
\text { Fireman .. } \\
\text { Greaser .. } \\
\text { Trainee engineer } \\
\text { Cook .. } \\
\text { Galley boy ... } \\
\text { Radio-operator }\end{array}$ & $\begin{array}{l}\cdots \\
\cdots \\
\cdots \\
\cdots \\
\cdots \\
\cdots \\
\cdots \\
\cdots \\
\cdots \\
\cdots \\
\cdots \\
\cdots\end{array}$ & $\begin{array}{l}\ldots \\
\cdots \\
\cdots \\
\cdots \\
\cdots \\
\cdots \\
\cdots \\
\cdots \\
\cdots \\
\cdots \\
\cdots \\
\cdots\end{array}$ & $\begin{array}{l}\ldots \\
\cdots \\
\cdots \\
\cdots \\
\cdots \\
\cdots \\
\cdots \\
\cdots \\
\cdots \\
\cdots \\
\cdots \\
\cdots \\
\end{array}$ & $\begin{array}{l}\cdots \\
\cdots \\
\cdots \\
\cdots \\
\cdots \\
\cdots \\
\cdots \\
\cdots \\
\cdots \\
\cdots \\
\cdots \\
\cdots \\
\cdots \\
\cdots \\
\end{array}$ & $\begin{array}{l}\ldots \\
\cdots \\
\ldots \\
\ldots \\
\cdots \\
\ldots \\
\ldots \\
\ldots \\
\cdots \\
\cdots \\
\cdots \\
\cdots \\
\cdots \\
\cdots\end{array}$ & $\begin{array}{l}\cdots \\
\cdots \\
\cdots \\
\cdots \\
\cdots \\
\cdots \\
\cdots \\
\cdots \\
\cdots \\
\cdots \\
\cdots \\
\cdots \\
\cdots \\
\cdots \\
\end{array}$ & $\begin{array}{l}- \\
\bar{Z} \\
20 \cdot 0 \\
1 \cdot 5 \\
12 \cdot 7 \\
\overline{-} \\
\bar{Z} \\
\overline{9 \cdot 7} \\
4 \cdot 3 \\
7 \cdot 7 \\
-\end{array}$ & $\begin{array}{c}\overline{5} \\
4 \cdot 0 \\
12 \cdot 2 \\
2 \cdot 0 \\
2 \cdot 5 \\
- \\
- \\
- \\
\overline{10} \\
0 \cdot 9 \\
5 \cdot 1\end{array}$ & $\begin{array}{r}0 \cdot 6 \\
24 \cdot 5 \\
25 \cdot 6 \\
13 \cdot 7 \\
18 \cdot 4 \\
40 \cdot 8 \\
1 \cdot 2 \\
8 \cdot 7 \\
3 \cdot 1 \\
16 \cdot 3 \\
\overline{7} \cdot 7 \\
0 \cdot 9 \\
2 \cdot 9\end{array}$ & $\begin{array}{r}1 \cdot 3 \\
17 \cdot 0 \\
18 \cdot 6 \\
18 \cdot 5 \\
19 \cdot 6 \\
7 \cdot 1 \\
2.6 \\
1.0 \\
13 \cdot 9 \\
- \\
- \\
2.1 \\
126.7 \\
-\end{array}$ & $\begin{array}{c}14 \cdot 2 \\
19 \cdot 0 \\
35 \cdot 6 \\
31 \cdot 8 \\
52 \cdot 3 \\
\overline{46 \cdot 3} \\
4 \cdot 3 \\
2 \cdot 8 \\
\overline{21 \cdot 7} \\
1 \cdot 0 \\
- \\
\end{array}$ & $\begin{array}{c}\overline{168 \cdot 5} \\
\overline{-} \\
38 \cdot 8 \\
354 \cdot 7 \\
- \\
\overline{59 \cdot 1} \\
21 \cdot 6 \\
- \\
\overline{11 \cdot 5} \\
-\end{array}$ & $\begin{array}{r}2.9 \\
18 \cdot 4 \\
22 \cdot 0 \\
17 \cdot 7 \\
16 \cdot 8 \\
14 \cdot 2 \\
10.3 \\
4 \cdot 6 \\
9 \cdot 0 \\
4 \cdot 5 \\
2 \cdot 7 \\
13.3 \\
11.0 \\
2.0 \\
\end{array}$ \\
\hline All trawlermen & . & $\cdots$ & $\cdots$ & .. & .. & .. & $13 \cdot 6$ & $8 \cdot 2$ & $12 \cdot 2$ & $12 \cdot 6$ & 23.9 & $36 \cdot 0$ & $13 \cdot 8$ \\
\hline
\end{tabular}

TABLE 12

Grimsby Deep Sea Fishermen 1963: Rate of InCAPACITy due to InJuRy in various Age Groups, SHOWING NATURE OF INJURY

\begin{tabular}{|c|c|c|c|c|c|c|c|c|c|c|c|c|c|}
\hline \multirow{2}{*}{\multicolumn{7}{|c|}{ Nature of injury }} & \multicolumn{6}{|c|}{ Age of trawlerman } & \multirow{2}{*}{$\begin{array}{c}\text { All } \\
\text { ages }\end{array}$} \\
\hline & & & & & & & $11-20$ & $21-30$ & $31-40$ & $41-50$ & $51-60$ & $61-70$ & \\
\hline $\begin{array}{l}\text { Contusion } . . \\
\text { Laceration ... } \\
\text { Crush injury } \\
\text { Amputation } \\
\text { Fracture and dislo } \\
\text { Sprain and strain } \\
\text { Eye injury ... } \\
\text { Burn and scald } \\
\text { Infected trauma }\end{array}$ & $\begin{array}{l}. . \\
. \\
. \\
\text { cation } \\
\ldots \\
\ldots \\
\ldots \\
.\end{array}$ & $\begin{array}{l}\cdots \\
\cdots \\
\cdots \\
\cdots \\
\cdots \\
\cdots \\
\cdots \\
\cdots \\
\cdots\end{array}$ & $\begin{array}{l}\cdots \\
\cdots \\
\cdots \\
\cdots \\
\cdots \\
\cdots \\
\cdots \\
\cdots \\
\cdots\end{array}$ & $\begin{array}{l}\cdots \\
\cdots \\
\cdots \\
\cdots \\
\cdots \\
\cdots \\
\cdots \\
\cdots\end{array}$ & $\begin{array}{l}\cdots \\
\cdots \\
\cdots \\
\cdots \\
\cdots \\
\cdots \\
\cdots \\
\cdots\end{array}$ & $\begin{array}{l}\cdots \\
\cdots \\
\cdots \\
\cdots \\
\cdots \\
\cdots \\
\cdots \\
\cdots \\
\cdots\end{array}$ & $\begin{array}{l}0.5 \\
1.4 \\
0.5 \\
1.9 \\
5.4 \\
1.1 \\
0.3 \\
3.1\end{array}$ & $\begin{array}{l}1.7 \\
0.7 \\
0.2 \\
2.5 \\
0.8 \\
0.6 \\
0.2 \\
1.3\end{array}$ & $\begin{array}{l}2.4 \\
0.9 \\
0.5 \\
0.1 \\
5.0 \\
1.5 \\
0.1 \\
0.6 \\
1.0\end{array}$ & $\begin{array}{l}2 \cdot 4 \\
0 \cdot 8 \\
0 \cdot 0 \\
0 \cdot 4 \\
2 \cdot 9 \\
1 \cdot 8 \\
1 \cdot 0 \\
0 \cdot 7 \\
2 \cdot 8\end{array}$ & $\begin{array}{r}4.5 \\
1.8 \\
0.7 \\
1.9 \\
11 \cdot 4 \\
2.7 \\
- \\
\overline{0}\end{array}$ & $\begin{array}{c}4 \cdot 2 \\
- \\
\bar{Z} \\
22 \cdot 3 \\
3 \cdot 9 \\
\overline{-} \\
5 \cdot 6\end{array}$ & $\begin{array}{l}2 \cdot 3 \\
1 \cdot 0 \\
0 \cdot 3 \\
0.7 \\
5 \cdot 1 \\
1 \cdot 5 \\
0 \cdot 4 \\
0 \cdot 4 \\
1.8\end{array}$ \\
\hline \multicolumn{7}{|c|}{ All injuries (including frostbite, asphyxia, and electric } & $13 \cdot 6$ & $8 \cdot 2$ & $12 \cdot 2$ & $12 \cdot 6$ & $23 \cdot 9$ & $36 \cdot 0$ & $13 \cdot 8$ \\
\hline
\end{tabular}


at sea (Table 10). The highest rate of incapacity occurred in the 61-70 age group followed by the 51-60 age group (Table 11). The lowest rate was in the $21-30$ age group.

Contusions, lacerations, and crush injuries caused most incapacity in the 51-60 age group (Table 12) and amputations in the 20 and under and 51-60 age groups. The greatest incapacity due to fractures, sprains and strains, and infected traumata occurred in the 61 and over age group. Incapacity rates were also high in the 51-60 age group due to fractures and sprains and strains, and in the 20 and under age group due to infected traumata.

The highest incapacity rate was recorded for third hands (Table 10) followed by mates, deck hands, deck trimmers, and deck learners, all of whom work on deck. The remainder were below the rate for all trawlermen. Of the engine room personnel, the chief engineer had the highest incapacity rate. The lowest rate was for radio-operators. Trainee engineers and skippers also had low incapacity rates.

The highest incapacity rate in trawlermen of all ratings was caused by fractures and dislocations, followed by contusions, infected traumata, sprains and strains, and lacerations (Table 10).

Certain incapacity rates are misleading due to the small number of man-days at sea of certain ratings in particular age groups (Table 11). For mates the incapacity rate of 168.5 per 1,000 man-days at sea in the 61-70 age group was due to the incapacity of two mates who had contusions. In the same age group the incapacity rate for deck trimmers was 354.7 per 1,000 man-days at sea, due to the incapacity of two deck trimmers. One injured his knee when he slipped on deck, suffering a contusion for which he was admitted to hospital. The other fell when disembarking, spraining his left wrist. An incapacity rate of 126.7 per 1,000 man-days at sea in the $41-50$ age group for galley boys (assistant cooks) was due to the incapacity of a trawlerman with a pulp infection of a finger, who also had Buerger's disease. Second engineers had a rate of 59.1 in the 61-70 age group. This was due to the incapacity of two second engineers who had fractures as a result of injury.

\section{Morbidity due to injury ashore}

Trawlermen are eligible for accident insurance benefit from their Fisherman's Insurance Scheme for injuries which occur ashore. There were 10 such injuries, two of which occurred in Iceland and were logged in the Official Trawler Log-book because the fishermen were signed on articles at the time of injury. Five injuries resulted in fractures, two each in contusions and sprains, and one in a laceration. Of the 10 trawlermen, three were deck hands, three were chief engineers, and the remainder were a mate, third hand, fireman, and cook.

There was a total period of incapacity of 291 days due to these injuries, giving an incapacity rate for trawlermen due to injuries ashore of 0.4 per 1,000 man-days at sea.

\section{Casualties to the boat}

The skipper of a fishing vessel is required to record in the Official Trawler Log-book a Record of Casualties to the Boat (Merchant Shipping Act, 1894). There is provision for this in the log-book under the following headings: Date; Place; Nature of Casualty; Cause of Casualty; Signature of Skipper or Person in Charge; Signature of some Member of the Crew.

During 1963, skippers logged 18 'casualties to boats' in respect of trawlers sailing from Grimsby (Table 13). Six trawlermen sustained injury or disability as a result and there were two deaths.

TABLE 13

Causes of 'Casualties to the Boat' as RECORDED IN GRIMSBY TRAWLER LOG-BOOKS IN 1963, SHOWING THE NUMBER OF RESUlTING INJURIES OR DEATHS TO TRAWLERMEN

\begin{tabular}{|c|c|c|c|}
\hline $\begin{array}{c}\text { Cause of } \\
\text { casualty to boat }\end{array}$ & $\begin{array}{c}\text { No. of } \\
\text { casualties } \\
\text { to boat }\end{array}$ & $\begin{array}{c}\text { No. of } \\
\text { resulting } \\
\text { injuries to } \\
\text { trawlermen }\end{array}$ & $\begin{array}{c}\text { No. of } \\
\text { resulting } \\
\text { deaths to } \\
\text { trawlermen }\end{array}$ \\
\hline $\begin{array}{l}\text { Collision } \\
\text { Damaged by high seas } \\
\text { Caught in ice. } \\
\begin{array}{l}\text { Aground } \\
\text { During boat drill }\end{array} \\
\begin{array}{l}\text { Fire on board } \\
\text {. . }\end{array}\end{array}$ & $\begin{array}{l}9^{1} \\
2 \\
1 \\
1 \\
1 \\
4\end{array}$ & $\frac{1}{-}$ & $\frac{-}{-}$ \\
\hline Total .. & 18 & 6 & 2 \\
\hline
\end{tabular}

${ }^{1}$ Three occurred in fog.

\section{Morbidity due to illness}

In 1963, 116 illnesses were suffered by trawlermen (Table 6).

As for injuries, the main source of information about illnesses was the Official Trawler Log-book. In it were details of the duration of periods of incapacity at sea. Further information was available from other sources, but there were few accurate details of the duration of incapacity ashore.

No benefit is paid for illness under the Fisherman's Insurance Scheme with the exception of that due to inguinal hernia. Therefore, there was no accurate record of the number of days of incapacity ashore for illness, other than hernia, at the Grimsby Exchange Clinic. The only source was the records of the Ministry of Pensions and National Insurance. This, as explained, was obtained from the Ministry for 47 trawlermen. In addition, information was received about a fisherman who had died at the time information was requested. 
TABLE 14

Grimsby Deep Sea Fishermen 1963: Number of Days of InCAPacity and InCAPACITy Rates ${ }^{1}$ Per 1,000 MaN-DAyS at Sea due to Illness by Rating

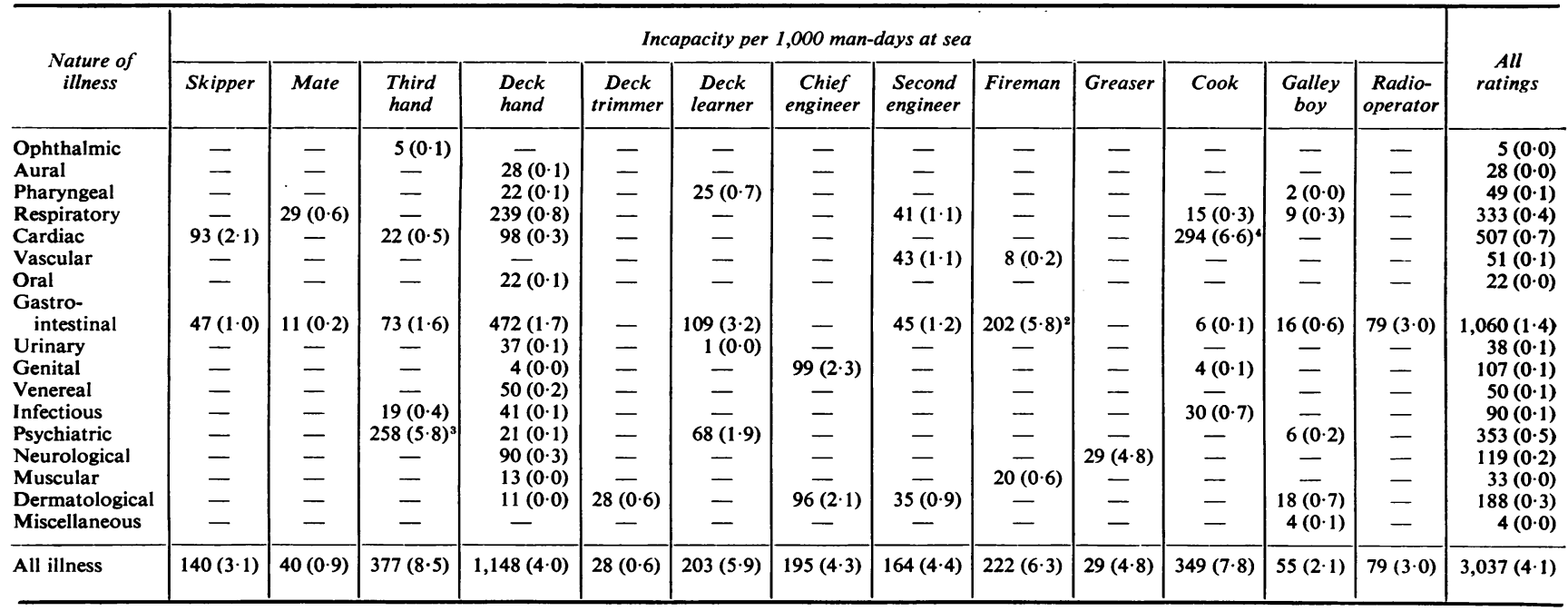

'Incapacity rates are shown in parentheses.

${ }^{2}$ Due to the illness of a fireman who also had hypertension.

${ }^{3}$ Due to the illness of two third-hands suffering from 'a nervous breakdown' and acute depression respectively.

'Due to the illness of a cook who had angina.

Injury and sickness benefit recorded by the Ministry of Pensions and National Insurance The Ministry of Pensions and National Insurance forwarded data under the following headings: Period of Incapacity during 1963; Type of Benefit; and Cause of Incapacity.

Thirty-two fishermen received sickness benefit, five injury benefit, one sickness and injury benefit, and 10 made no claim. One fisherman received sickness benefit for three spells of incapacity in 1963. The duration of most spells lay between 10 and 50 days (22 of 34 spells) and three were over 100 days (191, 242, and 398 respectively). Where incapacity continued outside the year 1963, only those days of incapacity in 1963 are used in the calculation of incapacity rates.

Accuracy of logged diagnosis In 19 of the 41 illnesses which were logged by the skipper and certified for National Insurance purposes by the general practitioner, the diagnosis was the same. Of the 22 remaining, 15 showed a difference only in terminology, the layman's as against the professional's, e.g., heart attack and angina. Only three showed a definite difference and, even here, the skipper was very close in his diagnosis, e.g., burst ulcer, logged by the skipper, and cholecystitis, as diagnosed by a medical practitioner. This, therefore, shows a remarkable degree of accuracy in the recording of illness by trawler skippers.
Total numbers of spells and days of incapacity There were 81 spells and 3,037 days of incapacity. The average length of a spell of incapacity was $37 \cdot 4$ days. Most days lost were due to abdominal disease (Table 14) followed by cardiac, psychiatric, and respiratory disease. Most days were lost by deck hands, firemen, third hands, and cooks.

Rate of incapacity The main source of accurate information on incapacity ashore was the Ministry of Pensions and National Insurance. Forty spells had a total of 2,386 days incapacity. Details of a further 41 spells and 651 days of incapacity were gained from other sources, e.g., general practitioners, hospitals, the Grimsby Exchange Clinic, and the Special Treatment Centre. No information about the duration of the remaining 35 spells was discovered. The total incapacity due to illness is, therefore, under-estimated. However, calculating from the total number of days of incapacity in 1963, as recorded $(3,037$ days), the incapacity rate due to illness in Grimsby trawlermen is shown in Table 14. The incapacity rate was highest for gastro-intestinal illness followed by cardiac, psychiatric, respiratory, and skin diseases in that order. The highest incapacity rate due to illness was in firemen, followed by third hands and cooks.

Monthly and seasonal incidence of injuries and illnesses

There was no marked difference in the monthly 
incidence, and the seasonal incidence showed that most injuries occurred in the winter months and least in the summer months. Fishing continues all the year round. The high incidence in winter is probably due to the worse weather and extreme conditions of work.

With the exception of respiratory tract illnesses, half of which occurred in the winter months of December, January, and February, there was no marked difference in the monthly and seasonal incidence of illness.

Comparison of morbidity due to injury and illness of deck men and other ratings

A comparison of the morbidity of those ratings working on deck in dangerous conditions and in all weathers has been made with that of other ratings not so exposed. Although both groups would be affected by injuries due to the erratic motion of the ship, only those on deck would be exposed to the hazards of fishing, e.g., caused by manoeuvring of deck apparatus, the handling of the trawl gear, and the weather, be it gale, frost or snow or seas coming on board. Illness would be likely to affect both groups to a similar extent.

The crews were, therefore, divided into two groups, deckmen and other ratings. The deckmen were the skippers, mates, third hands, deck hands, deck trimmers, and deck learners. The others were the chief and second engineers, firemen, greasers, trainee engineers, cooks, galley boys, and radiooperators. The writer, on first consideration, assumed that skippers should not be included with the deck men as most of their time is spent on the bridge. However, they have been included because, as they pointed out, when the trawl gear becomes fastened or fouled in any way, skippers go on deck to advise and assist and are exposed to the risk of injury at a particularly dangerous time. Also, skippers on North Sea trawlers which carry a smaller crew occasionally give a hand on deck.

The incapacity rates due to particular injuries and all injuries and due to all illnesses in deckmen and the other ratings have been calculated and are shown in Table 15.

Injury Taking all the injuries, frostbite, asphyxia, and electric shock together, the incapacity rate for deckmen was just over twice as great as that for other ratings. The incapacity rate due to all the lesions resulting from injury except burns and scalds was greater for deckmen than for other ratings. For contusions, amputations, fractures and dislocations, sprains and strains, and lacerations it was at least twice as great. For burns and scalds the incapacity rate was 10 times greater for other ratings than for deck-men, due almost entirely to the incapacity of cooks.
TABLE 15

GrIMSBY DeEP SEA FisheRMEN 1963: INCAPACITY RATES PER 1,000 MAN-DAYS AT SEA OF DECK Men AND THE Remainder OF THE CReW DUE TO INJURIES AND ILLNESSES

\begin{tabular}{|c|c|c|c|c|c|}
\hline \multirow{2}{*}{\multicolumn{3}{|c|}{ Cause of incapacity }} & \multicolumn{2}{|c|}{ Rating 1} & \multirow{2}{*}{$\begin{array}{c}\text { All } \\
\text { ratings }\end{array}$} \\
\hline & & & Deck men & Others & \\
\hline $\begin{array}{l}\text { Contusion ... } \\
\text { Laceration ... } \\
\text { Crush injury } \\
\text { Amputation. . } \\
\text { Fracture and dislo } \\
\text { Sprain and strain } \\
\text { Injury to eyes } \\
\text { Burn and scald } \\
\text { Infected trauma } \\
\text { Frostbite .. } \\
\text { Asphyxia .. } \\
\text { Electric shock }\end{array}$ & $\begin{array}{l}\cdots \\
\cdots \\
\ldots \\
\cdots \\
\text { cation } \\
\cdots \\
\cdots \\
\cdots \\
\ldots \\
\cdots \\
\cdots\end{array}$ & $\begin{array}{l}\ldots \\
\cdots \\
\cdots \\
\cdots \\
\cdots \\
\cdots \\
\cdots \\
\cdots \\
\cdots \\
\cdots\end{array}$ & $\begin{array}{l}2 \cdot 7 \\
1 \cdot 2 \\
0 \cdot 4 \\
0 \cdot 8 \\
6 \cdot 4 \\
1 \cdot 9 \\
0 \cdot 6 \\
0 \cdot 1 \\
2 \cdot 1 \\
0 \cdot 0 \\
0 \cdot 0 \\
-\end{array}$ & $\begin{array}{l}1.2 \\
0.6 \\
0.3 \\
2.7 \\
0.8 \\
0.0 \\
1.0 \\
1.4 \\
\overline{0.0} \\
0.0\end{array}$ & $\begin{array}{l}2 \cdot 3 \\
1 \cdot 0 \\
0.3 \\
0.7 \\
5 \cdot 7 \\
1 \cdot 5 \\
0.4 \\
0.4 \\
1 \cdot 8 \\
0.0 \\
0.0 \\
0.0\end{array}$ \\
\hline All injuries .. & $\cdots$ & $\cdots$ & $16 \cdot 5$ & $8 \cdot 1$ & $13 \cdot 8$ \\
\hline All illnesses & $\cdots$ & $\cdots$ & 3.9 & $5 \cdot 4$ & $4 \cdot 1$ \\
\hline
\end{tabular}

${ }^{1}$ See text.

Illness Although information on illness was not complete, from that available it was found that other ratings had a greater incapacity rate due to illness. It was 1.4 times the rate for deckmen.

\section{Unfit trawlermen at sea}

Many men who are unfit or have actual disability are sailing on trawlers. Not only are they not prevented from sailing but they are often encouraged to make up the crew of a trawler about to put to sea. Examples are described in Appendix I. Even trawlermen certified as permanently unfit for sea by the examining medical officer were found to have signed on articles. They returned to the clinic for the treatment of subsequent injury. Examples were fishermen with chronic otitis media and a duodenal ulcer and two with chronic bronchitis.

\section{Discussion}

\section{Sources of information}

Because of the poor and inadequate recording and the difficulty of keeping in touch with the deep sea fisherman, a retrospective study such as this gives a low estimate of the morbidity due to injury and illness (especially the latter). There is an obvious need, therefore, for a proper recording system of the medical histories of deep sea fishermen. It should be uniform at all ports, with a central agency for the collection and collation of medical statistics. Little information was received from overseas, even when requested. Of the 140 enquiries to hospitals overseas 
about the treatment of trawlermen, replies were received to 32 only. Often the only information received at the Grimsby Exchange Clinic was a brief radio message to the trawler owners that a trawlerman had been put ashore and often this was not relayed to the Clinic Medical Officer. It is suggested, therefore, that the trawlerman should carry a personal medical record card for use in the United Kingdom and overseas and at sea by the skipper and medical officer of the Fishery Protection Squadron. Skippers should be instructed on the filling in of the card and the kind of information required. There should also be arrangements for the return to the United Kingdom of records of hospital treatment overseas.

\section{The population at risk}

Because of their migratory nature, changing from ship to ship and port to port, there is no accurate information on the number of fishermen in the trawling industry, or of the time they spend at sea. Also trawlers are at sea for varying periods of time. Up to now it has not been possible to calculate mortality or morbidity rates for injury or illness or to make comparisons.

Such calculations and comparisons have been achieved in this investigation by measuring the actual number of man-days at sea sailed by Grimsby trawlermen in 1963 and the calculation of incapacity rates, a measure of morbidity and of mortality rates. Table 2, showing the number of man-days sailed by Grimsby trawlermen by age and rating in the year 1963, is, so far as the writer is aware, the only accurate measure of time spent at sea by deep sea fishermen for a particular period of time. It is used throughout this work as the measurement of the population at risk. The table also shows that trawlermen continue at sea to an older age than is generally believed in the industry. Approximately $40 \%$ of the man-days were worked by trawlermen aged 41 and over. However, they leave their occupation earlier than the shore worker and only $2 \%$ of the man-days were sailed by trawlermen aged 61 and over.

By estimating the number of men sailing (Table 3), and comparing this with statistics of registration, it has been shown that the latter are inaccurate as a measure of the number of men sailing, e.g., twice as many skippers and deck hands were registered as sailed, and three times as many galley-boys.

\section{Incidents affecting the health of deep sea fishermen in 1963}

In all, 837 incidents of injury, illness, and death in Grimsby deep sea fishermen occurring in 1963 were investigated. Although injury and illness occurred at sea, most spells of incapacity did not begin until the trawlerman was ashore as he continued to work whilst at sea.

It is well to bear in mind that the incapacity and mortality measured are for spells of incapacity and deaths due to injury and illness which occurred at sea. Except for some injuries $(10(1.2 \%)$ incidents) which occurred ashore while the trawlerman was signed on articles, records of injury or illness starting ashore and preventing the trawlerman from sailing were not investigated. Forty men whose records with the Ministry of Pensions and National Insurance were examined for illness occurring at sea had 13 spells of illness starting ashore, which would not have been discovered had these records not been perused. Although most of the injuries and illnesses have been investigated, the full extent of the incapacity of the group of trawlermen under investigation is not known.

\section{Mortality}

Ten of the 14 deaths (all the accidental deaths and four of those due to natural causes) were registered with the Registrar General of Shipping and Seamen. The cause of death as logged and as recorded in the monthly reports of the Registrar General of Shipping and Seamen agreed for accidental death but not for the three due to natural causes. In one, the postmortem examination showed the cause (left ventricular failure) to differ from that registered (suspected coronary thrombosis) but the Registrar General informed the writer of the revised diagnosis. In another, the logged diagnosis was coronary thrombosis and that registered, myocardial fibrosis; and in the third the registered cause of death was 'natural causes' and the logged diagnosis was coronary thrombosis. The diagnosis of the cause of death as logged by the skipper was remarkably accurate for accidental causes and not widely out for natural causes. The deaths are those of trawlermen who died at sea from injury, or at sea or ashore from illness which began at sea.

All the accidental deaths occurred at sea and by and large were in the younger age groups; only two were in trawlermen over 40. Deaths from natural causes were in the older age groups and included only one trawlerman under 40 years.

The mortality rate due to natural causes as a result of illness which began at sea was $3 \cdot 3$ per 1,000 for Grimsby trawlermen, as compared with the mortality rate of 7.7 per 1,000 for males of England and Wales in 1963 in the 15-69 age group, due to natural causes, i.e., deaths from all causes less those due to accident, poison, and violence (external causes), as calculated from the Medical and Population Tables of the Registrar General (1965). The bias of the group under study, the unfit men having left the industry for shore jobs and their deaths not being recorded as that of trawlermen, is thus illustrated. A true picture of mortality due to natural causes can only be discovered by a prospective study and the follow-up of all trawlermen who go ashore. At the 
present time one such study is being undertaken in Aberdeen by Miss Joyce Harley and Professor F. M. Backett (personal communication).

Because of fluctuations in the number of deaths due to casualties to vessels, fatal accident rates of fishermen vary from year to year. Schilling (1966) calculated the mean annual fatality rates of fishermen over periods of years to be about 1 per 1,000 and compared them with the accidental death rates of other occupations. He found them to be twice the rate for coalminers and about 20 times the rate for manufacturing industries. He commented that it had not been possible to calculate death rates with a high degree of accuracy since there are difficulties in estimating the population at risk', or 'to get separate rates for trawling which is believed to be the most hazardous method of fishing'. The death rate due to accidental causes in 1963 was 2.4 per 1,000 . In that year there was no foundering or loss of Grimsby trawlers. The rate is therefore twice that of the mean annual fatality rate of fishermen of the United Kingdom, as calculated by Schilling, and therefore four times the rate for coalminers and 40 times the rate for manufacturing industries.

\section{Injury}

The extent of the injuries was poorly described whether by the skipper or by medical practitioners. Most of those logged as contusions involved large areas of damage to skin and subcutaneous tissues and included injuries which, for example, caused loss of consciousness and the use of morphia to relieve pain. Fishermen were also rendered unconscious by injuries described as lacerations and sprains and strains. Three trawlermen received the maximum of $\mathfrak{£ 7 5 0}$ compensation from the Fisherman's Accident Insurance Scheme following injury, because of permanent loss of normal vision, loss of sight of an eye, and permanent disability of an arm following multiple fractures.

All the injuries except burns and scalds, frostbite, asphyxia, and electric shock, i.e., $94.7 \%$ of those investigated, were due to trauma. Millar (1959) of the Fishery Protection Squadron also noted that the majority of his patients suffered from trauma.

Contusions were more than twice as frequent as the second most common injury, infected trauma. The high incidence of contusions is not surprising, considering the size and weight of the apparatus manoeuvred. Goethe, Rinck, and Gudmundsson (1959) and Leiper (1966) also found septic infections of the hands and fingers second in order of incidence to accidents (presumably injury due to accident) by the former and to injury of the back and shoulder by the latter. Septic hands and fingers were most common in the series of injuries described by Macqueen (1954), and Grant (1961) noted that septic skin lesions caused most trouble. In former years Burns (1955) had found that septic infections were most common but, at the time of writing, crush injury had become more common.

Under the heading of infected trauma the writer has included only those injuries which became infected. Three cases of boils and five of salt water boils are included as dermatological conditions. Had boils and salt water boils been included with infected trauma, the order of incidence would not have been altered.

Almost half (49.9\%) of the total injuries involved the upper limb, just under one third $(29.5 \%)$ of which became infected. More than two thirds $(68.8 \%)$ of the upper limb injuries involved the hands and fingers, of which $38.2 \%$ became infected. Most of the puncture wounds, crush injuries, fractures and burns and scalds also involved the upper limb. Popham (1957), in Cape of Storms, an account of a trawler voyage to the Arctic fishing grounds, has noted the fisherman's proneness to injury of the hand. 'Only if you were to look at their hands might you guess their trade; fingers missing, abbreviated or deformed, are the fisherman's mark and few get their bosun's ticket with hands unscathed'. Many fishermen return to sea after finger amputation.

\section{Incapacity due to injury}

More than half $(56.3 \%)$ of the trawlermen whose injuries were recorded were incapacitated by their injuries, i.e., were off work at sea, at sea and ashore or ashore.

The high incapacity rate of third hands was especially due to fractures, contusions, sprains and strains, and infected traumata. His particular duties in connexion with the cod-end, e.g., manhandling it into position, may contribute to his injuries. Removing his gloves to untie the cod-line in a stream of fish slime, grit, and sea water makes him more prone to infected lesions.

The high incapacity rate from lacerations and infected traumata for deck learners is possibly due to their inexperience in handling the knife and fish. The young deck hand (aged 20 and under) had a relatively high incapacity rate. The rate for deck learners in the same age group was lower. This probably indicates the inexperience of the young deck hand, called upon to undertake duties of a dangerous nature not asked of the deck learner.

The high rate of incapacity caused by sprains and strains, almost as great as that of infected traumata, is indicative of the physical effort required in handling heavy gear and working under unnatural conditions.

\section{Occupational safety}

In the report 'Safety on Board Fishing Vessels' (International Labour Organization, 1962), it was 
noted that occupational safety on board fishing vessels had hardly been dealt with at a national level, and many countries (including the United Kingdom) have no regulations, codes of practice or other provisions covering this question. The only extensive national occupational safety regulations for the fishing industries appear to be those in force in Canada, Eire, the Federal Republic of Germany, Japan, and Norway.

In co-operation with the Food and Agriculture Organization and the Inter-governmental Maritime Consultative Organization, it was recommended that the International Labour Organization should draw up a comprehensive and detailed model code of safety regulations for mechanically propelled fishing vessels. It produced its draft contribution (International Labour Organization, 1966), which consisted of a set of general rules primarily concerning aspects of occupational safety on board fishing vessels. Although only a working paper which is still subject to revision, it should be examined in its present form by those concerned with the safety of fishermen.

The statutory occupational safety requirements for British fishing vessels are very few and require fishing vessels to carry life-saving and fire-fighting appliances (Merchant Shipping Act 1894 and amendments). There are, however, two Notices to Owners, Builders and Skippers of Fishing Vessels, No. M. 434 of the Ministry of Transport (1959) and No. M. 511 of the Board of Trade (1966), which make recommendations on the use of life lines and the operation of the winch respectively. As far as the writer is aware, these are the only comment from official sources on the prevention of occupational injury on British fishing vessels. It is necessary, therefore, that legislation to protect the fisherman from accident and its consequences be enacted in the United Kingdom, as has been done for the shore worker and for fishermen in other countries. Accidents causing injury and/or death should be made notifiable and they should be properly recorded and thoroughly investigated. Safety officers with a practical knowledge of the workings of the trawler should be appointed by trawler owners, to whom accidents would be reported at the end of a voyage. They would be responsible for investigation on the spot and their reports would build up a wealth of evidence for further research into accident prevention. The method of reporting should be uniform in all ports, and instructions to skippers should state the kind of information required. The establishment of an inspectorate with legislative powers of inspection and investigation as under the Factories, Mines and Quarries and Agriculture Acts could co-ordinate this work at all ports and provide a means for the collection and collation of records.

In this study, it was shown that injuries were caused by falls $(17.9 \%)$, trapping $(14.6 \%)$, blows
(13.9\%), slipping (11.1\%), and being knocked down by the sea $(4.9 \%)$ and falling objects $(3.9 \%)$, and the incapacity rate due to injury for deckmen was just over twice that for other ratings. In addition to the trawlerman's usual movement about the ship as on a merchant vessel, he has to undertake heavy and strenuous work at sea. To assist him to maintain his balance in the awkward motion of the ship, adequate hand rails and safety lines should be provided. Decks on trawlers are continuously wet from seas coming on board, and water flows from the washing machine at all times, even in the calmest weather. As gutting progresses, the entrails of fish add to the hazard of slipping. To prevent slips and falls the decks or at least the immediate working area should be surfaced with a non-slip material. Suitable matting, properly laid, in the engine room and elsewhere would give a surer footing to trawlermen.

The warps and winch cause many injuries and should be guarded. When warps break they cause serious injury. Wear and tear causes strands of wire to break free and project from the warp, causing puncture wounds to hands and limbs. Wire strands and splicing on the warps have been known to catch on clothing, drawing limbs into bollards and winches. Warps should, therefore, be regularly inspected and replaced when necessary and, at least, at fixed intervals of time.

Tackle and trawl gear swinging about have caused serious injury and death. In this survey 54 men were injured in this way, one of whom received fatal injuries. Special care should be taken in their use and they should be properly secured when not in use. Another cause of injury has been the slamming of doors. These should be fastened back or properly closed at all times.

Of the injuries which became infected, $60.5 \%$ were caused by puncture wounds of the fingers and hands due to wire strands from the warp or fish bones. To prevent infection, proper attention must be given to the cleanliness of hands, gloves, and gutting knives. Heavy gloves should be worn for the handling of the trawl gear and as protection against wire pricks. If necessary, a lighter glove could be used for gutting. The gloves should be changed and washed regularly and the hands thoroughly cleaned in an antiseptic solution before putting on a fresh pair of gloves. First aid to wounds, especially pricks (the treatment of which is usually ignored), should be carried out as soon as possible after injury. First aid boxes should be placed at convenient places on the ship to encourage their use. Often it is too troublesome to get at the medicine chest and wounds are neglected.

Because the modern trawler, with heavier gear and more powerful machinery, can operate in poor weather conditions, the risk of accident is greater and a skipper may be tempted to prolong fishing 
even when the weather is worsening. In 1963, 17 injuries were logged as occurring in bad weather and 34 trawlermen were knocked down by heavy seas. Regulations should limit trawling operations in bad weather.

Many accidents are peculiar to deep sea fishermen, particularly those which take place on the conventional side trawler. Here the method of hauling and shooting has not changed since the days of the sailing smack, 100 years ago. On the stern trawler the gear is shot and hauled along a ramp in the stern and fish are released into a compartment below decks. Injuries, especially of the arms, hand, and fingers, are likely to be less because manhandling over the side has been eliminated. Gutting takes place below deck and the trawlerman is under cover from the elements and will not be knocked down by heavy seas. The Polish trawl fleet has no side trawlers and the impression is that fatalities and injuries have been greatly reduced (Fishing News, April 14, 1967). The fleets of the United Kingdom are gradually changing to the stern trawling type of vessel, but these will remain a small proportion of the fleet for some time. Change-over to stern trawlers will improve environmental circumstances and reduce the likelihood of accidents. Further research could investigate and compare the incidence of injury and accidental death on the two types of trawler.

At the present time physically unfit trawlermen go to sea. Also in recent years it has been recognized within the industry that the quality of the new entrant has deteriorated. In this dangerous occupation where team-work and quick reflexes and reactions of trawlermen are essential, lowering of standards can only result in increased risk of injury. An attempt is being made to improve conditions to attract suitable men. The gradual raising of the entrance requirements and the prevention of unfit men going to sea will produce the trawlerman who is capable and willing to participate actively in accident prevention measures.

\section{Measures to promote the prevention of accidents}

The trawlerman accepts the fact that accidents are part of his occupation. Owners, too, have the same attitude and, although more enlightened companies have taken some measures in accident prevention, there is still the feeling that accidents will happen whatever efforts are made. One basic reason for the lack of social concern and action is that the folklore of accidents is perhaps the last folklore subscribed to by rational men, including well-educated professionals who have been trained to identify and reject folklore in their own areas of competence (Haddon, Suchman, and Klein, 1964). 'Luck', 'chance', and 'acts of God' are all culturally acceptable explanations of accidents, although such concepts have gradually fallen into disuse in explaining the causation of disease.

The deep sea fisherman is naturally superstitious. It is vital, therefore, that the individual trawlerman is reached to make him accident conscious and to impress upon him the idea that accidents can be prevented, and that the fatalistic attitude to disablement and death is broken down. At the outset of this study, on being shown over a trawler for the first time by an experienced skipper, the writer was assured that, as everything possible was being done to prevent accidents, the accident rate could not be reduced. Another skipper in an address had this to say: 'When one has ridden out the terrifying forces of an Atlantic gale, when one has experienced as I have the helplessness of being washed overboard and back again, then the insistence on carrying out piddling little safety precautions the next moment is distasteful. Fishermen are confirmed fatalists. They will not wear life jackets, there is the basic fear of restriction that would hamper their movements in avoiding dangers on board. I think they are probably right' (Roberts, 1966).

In the interests of safety the trawlerman should be allowed, without loss of pay, to attend ashore instruction on accident prevention, which could be incorporated with a course in first aid. Both subjects should receive emphasis in any pre-entry training scheme. The appointment of safety officers would indicate to the fisherman that the trawler owners had an interest in his personal safety. A reduction in time lost away from sea because of accidental injury would be an advantage to trawler owners.

A small news sheet with local fishing news was passed round on the 'Northern Gift'; it was read avidly by crew members, and was a topic for discussion. Where boredom is common, an attractive weekly or monthly publication incorporating notes on accident prevention would be welcomed. The trawlerman is interested in landing his catch in good condition, so that it will make the maximum price. The Torry Research Station Advisory Note, 'Take care of your catch' (Department of Scientific and Industrial Research, 1962), emphasizes cleanliness in handling and prevention of contamination of fish and, if followed, would go some way toward the reduction of hand infections and falls from slipping. The trawlerman's interest in the care of fish could be used to introduce and develop ideas of accident prevention.

Most raw recruits to the industry sign on articles and go straight to sea without any training whatsoever. Suggestions on accident prevention, such as are incorporated in the manual, Course for Apprentice Fishermen (World Fishing, 1964), should therefore be circulated to trawlermen, particularly to the new entrant.

Your Safety Aboard Ship (The Shipping Federation 
Ltd., and the Employers' Association of the Port of Liverpool, 1966) is a booklet which depicts hazards met with on the merchant vessel, and is a fine example of one approach which could be used in the fishing industry.

There are many attractive posters on accident prevention distributed on shore. Posters highlighting the various hazards of deep sea trawling could be used and changed at intervals. They would certainly brighten up the uninteresting surrounds of a trawler and be the focus for ribald comment, but the message could get home. Wood (1965) has described the accident prevention schemes undertaken in the coalmining industry and shown that the death rate and incidence of serious injury have decreased since they started in 1947. He mentions competitions between pits. In the fishing industry there is great but friendly rivalry between ports and between vessels sailing from the same port. The Silver Cod Trophy goes annually to the trawler which lands the largest catch over the year. This rivalry could be used to promote accident prevention schemes for deep sea fishermen.

\section{Casualties to boats}

Contrary to what might be expected, although half the casualties to boats were collisions, they caused little injury to trawlermen. The present study has shown that two deaths $(14.3 \%$ of the total) and four injuries, including asphyxiation $(0.6 \%$ of the total), were due to fire. Fires on board trawlers are often reported in the local press of fishing ports, outbreaks occurring even when vessels are tied up in dock. It is necessary that more attention be paid to the hazard of fire aboard trawlers and that fire prevention be included with the other measures of accident prevention.

\section{Illness}

As a result of the 116 illnesses in 1963, there were 81 spells and 3,037 days of incapacity. Special enquiry from the Ministry of Pensions and National Insurance concerning trawlermen about whom the writer required additional information on logged illness showed that they had other illnesses which were not logged. It is very probable that other trawlermen had illnesses, details of which are not recorded in this paper. From the figures noted above, the incapacity rate due to illness was $4 \cdot 1$ per 1,000 man-days at sea, and the average length of spell of illness was 37.5 days.

Because of the incompleteness of the information it is difficult to draw conclusions about the incidence of and incapacity caused by illness. However, from the data available, it was shown (Table 14) that for trawlermen with an illness, the incapacity rate was highest for gastro-intestinal disease, followed by cardiac, psychiatric, respiratory, and skin disease.
Of the 27 gastro-intestinal illnesses, five were due to appendicitis, all of which required appendicectomy overseas (one trawlerman had a perforated appendix after 12 days' illness at sea). Six illnesses were due to inguinal hernia, one of which was a possible acute strangulation and was treated by a medical officer of the Fishery Protection Squadron. Five of the six were attributed by the trawlermen to physical strain, e.g., pulling or lifting. Twelve trawlermen had illnesses described as 'stomach trouble' and 'stomach ulcers', of whom on examination three had gastritis. Goethe and his co-workers (1959) also found that for fishermen treated on two hospital ships there was a high incidence of disability due to diseases of the digestive tract, which, with diseases of the teeth, mouth, and jaw, were next to accidents and septic infections of the hands as a cause of disability.

Four illnesses were associated with alcoholism. A deck hand with hypertrophic gastritis was noted to be a heavy drinker, and a cook was landed 'with D.T.s'. Of two third hands who had anxiety states and depression respectively, one when put ashore was diagnosed on admission to hospital as 'intoxicatio', and the other had been drinking heavily, consuming, according to his wife, a bottle of whisky each day.

Five trawlermen were recorded as having venereal disease, confirmed in four cases and probable in the fifth. Venereal disease is less likely to be recorded than disease due to other causes. However, it is the writer's impression that it is less common among deep sea fishermen than among merchant seamen, as the trawlerman does not call at foreign ports except in an emergency, and on his return to port at the end of each voyage it is to his home and family that he goes.

Of certain diseases said to be peculiar to fishermen, e.g., salt-water boils, erysipeloid, and Dogger Bank itch, only five cases of salt-water boils were found in the present survey. Four men were deck hands and one was a deck trimmer. Salt water boils differ in no way from any chronic boil and yield to cleanliness, hot soaks, and prevention of further irritation (Schwartz, Tulipan, and Birmingham, 1957). Newhouse (1966), in the examination of 451 Lowestoft trawlermen, found salt-water boils (sea water boils) in $16(3.5 \%)$. The low incidence in Grimsby trawlermen is probably because only severe cases are logged by the skipper. Improved protective clothing, consisting of a polyurethane-coated nylon jacket and trousers, the former having an inner storm cuff in the sleeve which fits snugly around the wrist, is under trial at Lowestoft.

Erysipeloid, although often said to be a disease of fishermen, usually affects shore workers who handle stale fish. They are especially liable to infection in warm to hot weather. It is not associated with fresh fish and there were no logged cases in the trawlermen 
under study. During the two and a half years of attendance at the Grimsby Exchange Clinic, the writer noted only seven cases, all in shore workers. Of a series of 235 cases in Aberdeen in 1952 and 1953 (Proctor and Richardson, 1954), only two infections occurred in trawlermen.

Dogger Bank itch, caused by contact with Alcyonidium gelatinosium, did not affect Grimsby trawlermen in 1963 nor has it done so in recent years because Grimsby near-water trawlers do not fish the areas on the Dogger Bank and off the Danish coast where the 'weed' grows. Lowestoft trawlers do, and there was a high incidence of the itch in Lowestoft trawlermen in 1964 (Newhouse, 1966).

A peculiar condition, a conjunctivitis, was described by the clinic medical officer who had treated many cases in his long experience. It was caused by the juice of a sponge, known by the trawlermen as 'tit-juice', brought up from the sea-bed in the cod-end. The weight of fish causes juice to squirt from the sponge, resulting in severe irritation if it gets into the eyes. Of the two trawlermen with the condition seen by the writer, one had a severe conjunctivitis, a 'red-eye' with streaming lacrymation. The previous day he had complained of photophobia and had been unable to open his eyes.

\section{Injury and illness in trawlermen}

This is a self-selected group of trawlermen. Unfit trawlermen (but not all of them) who have left the sea and others who have gone ashore for other reasons, e.g., marriage or not liking the job, are not included. The inquiry has been made in full awareness of these limitations. Trawlermen who were ill were more likely to be off work, and for a longer period, than those injured. In comparing the morbidity due to injury and illness, it has to be remembered that, as illnesses have not been fully recorded, their incidence and the incapacity rates due to them will be lower than the actual. In this enquiry it was found that the incapacity rate due to injury was three times that due to illness. It therefore appears from the incapacity rate that the trawlerman is subject to a high degree of morbidity due to injury.

\section{The need for an occupational health service for trawlermen}

At the present time trawlers put to sea manned by deep sea fishermen, some of whom are medically unfit for the duties they are required to perform. They may cause needless worry to skippers, avoidable expense to owners, and loss of earnings to the crew when a ship has to put in to port. There should therefore be a compulsory pre-entry medical examination for all trawlermen so that those found to be unfit are barred from entering the occupation.
And there should be subsequent regular periodic medical examinations. At the present time most of the 'new entrants' who turn up for medical examinations for admission to the Fisherman's Insurance Scheme have been sailing for months and sometimes years. This should be part of a comprehensive occupational health service for all trawlermen with full-time medical officers at the major fishing ports. The trawler owners should see to it that trawlermen certified by the examining medical officer as unfit are barred from sailing.

An occupational health service would be of benefit to both trawler owners and deep sea fishermen. The improved health of trawlermen and the elimination of unfit men from the crews of trawlers would mean less absence from sea and fewer trawlers leaving the fishing grounds and consequently would lead to greater productivity and a high morale among deep sea fishermen.

Only when there is an accident prevention service and proper and adequate medical supervision for trawlermen with a central advisory and co-ordinating agency will there be an improvement in the health of deep sea fishermen, bringing them forward at last into 20th century working conditions and alongside their fellow workers ashore.

The writer wishes to acknowledge the ready co-operation he has had from the Grimsby trawler owners and deep sea fishermen in this research, and in particular to note the valuable assistance of Mr. T. Cooper, Secretary of the Trawler Owners' Association at the Grimsby Exchange Ltd., and the late skipper John Hobbs, Secretary of the Trawler Officers' Guild.

Dr. John Lanny has been the medical officer of the Grimsby Exchange Ltd. Clinic since its inception in 1936. The writer has appreciated his assistance in this investigation, and has benefited greatly from his expert knowledge of the deep sea fisherman.

\section{References}

Backett, E. M., and Harley, Joyce (1967). A study of the mortality of Aberdeen trawl fishermen for the period 1956-61. Unpublished. Personal communication.

Board of Trade (1966). Accidents involving Trawl Winches. Notice to Owners, Skippers and Crews of Fishing Vessels. Merchant Shipping Notice No. M.511. H.M.S.O., London.

Burns, J. (1955). Deep sea trawling and some of its medical problems. Tr. Ass. industr. med. Offrs, 5, 55-60.

Department of Scientific and Industrial Research. Torry Research Station (1962). Take Care of Your Catch. Torry Advisory Note No. 4. H.M.S.O., London.

Goethe, H., Rinck, G., and Gudmundsson, G. (1959). Erkrankungen in der deutschen Hochseefischerei mit Berücksichtigung des Gebisszustandes. (Sickness in German deep sea fishermen with reference to dentition.) Arch. Gewerbepath Gewerbehyg., 17, 57-66. Abstract in Bull. Hyg. 1959, 34, 773.

Grant, G. L. (1961). An Essay on Fishermen, Their Health and Their Society. Dissertation for the Diploma in Public Health, University of Aberdeen.

Haddon, W., Suchman, E. A., and Klein, D. (1964). Accident Research. Methods and Approaches, pp. 2 and 6. Harper \& Row, New York, Evanston, and London.

International Labour Organization (1962). Safety on Board Fishing Vessels. International Labour Office, Geneva. 
(1966). Occupational Safety on Board Fishing Vessels. Draft. Part A. Joint I.L.O./F.A.O./I.M.C.O. Project concerning a Code of Practice on Safety on Board Fishing Vessels. International Labour Office, Geneva. Personal communication.

Leiper, J. (1966). Medical services in fishing fleets. In Medical Services in Transport, ed. Grant, J. S., Heggie, R. M., and Norman, L. G. Pp. 125-136. Butterworths, London.

Macqueen, I. A. G. (1954). Some aspects of the health of trawl fishermen. An unpublished paper read at the Annual Conference of the Association of Sea and Air Port Health Authorities of the British Isles. Personal communication.

Medical Examination (Fishermen) Convention, 1959. Convention No. 113 concerning the Medical Examination of Fishermen. International Labour Office, Geneva.

The Merchant Shipping Act, 1894. H.M.S.O., London.

Millar, C. W. (1959). The Icelandic Fishery Protection Patrol. J. roy. nav. med. Serv., 45, 159-161.

Ministry of Transport (1959). Safety Rails and Lifelines on Fishing Vessels. Notice to Owners, Builders and Skippers of Fishing Vessels. No. M.434. H.M.S.O., London.

Newhouse, M. L. (1966). Dogger Bank itch: survey of trawlermen. Brit. med.J., 1, 1142-1145.

Popham, Hugh (1957). Cape of Storms, p. 20. Rupert Hart-Davis, London.

Proctor, D. M., and Richardson, I. M. (1954). A report on 235 cases of erysipeloid in Aberdeen. Brit. J. industr. Med., 11, 175-179.

Registrar General (1965). Statistical Review of England and Wales for the Year 1963. Part I, Tables Medical. Part II, Tables Population. H.M.S.O., London.

Roberts, D. A. (1966). What shall we do with the injured sailor? Unpublished paper read at a three-day residential course on Rehabilitation in Rural Areas (with special reference to Agricultural Workers and Fishermen), July 12-14, 1966. British Council for Rehabilitation of the Disabled. Personal communication.

Schilling, R. S. F. (1966). Trawler fishing: an extreme occupation. Proc. roy. Soc. Med., 59, 405-410.

Schwartz, L., Tulipan, L., and Birmingham, D. J. (1957). Occupational Diseases of the Skin, p. 837. 3rd ed. Henry Kimpton, London.

The Shipping Federation Limited and Employers' Association of the Port of Liverpool. (1966). Your Safety Aboard Ship. Edward Mortimer, Halifax and London.

Wood, W. A. (1965). Industrial safety-the coal mining industry. In Hunt, J. H. (ed.) Accident Prevention and I ife Saving: Papers given at a convention held at the Royal College of Surgeons of England, May 1963, p. 175-193. Livingstone, London.

World Fishing (1964). Course for Apprentice Fishermen, pp. 21 and 27. Grampian Press, London.

\section{Appendix I}

\section{Examples of unfit trawlermen sailing on Grimsby trawlers}

Of the trawlermen sailing in 1963, two had kidney disease, one having had 'a kidney operation' and another a kidney resection; two had had partial gastrectomies and one a peptic ulcer and two previous laparotomies; two had a previous history of a slipped disc, one of which necessitated immobilization for eight months, and a trawlerman with chronic osteomyelitis was sailing 'at his own risk'. A cook with five incidents of ill health in the year was put ashore on four occasions, twice on successive voyages, causing loss of fishing time and incurring additional expense to the owners. Another trawlerman with seven spells of illness in the year which ended with myocardial infarction had sailed on at least three voyages. Fishermen with defective vision sign on regularly even for deck duties. One deck-hand treated for injury had visual acuity of less than 6/60 and two had lost an eye. A cook who insisted on being put ashore, unnecessarily in the opinion of the skipper, unknown to him had an artificial limb. Two epileptic trawlermen were treated by medical officers of the Fishery Protection Squadron.

Trawlermen seen by the writer outside the year under study included the following: a chief engineer, who had had three attacks of coronary thrombosis and was certified as permanently unfit, died at sea, having sailed at his own risk; a skipper who, after treatment, still had a blood pressure of $210 / 150 \mathrm{~mm}$. $\mathrm{Hg}$, also returned to sea. A deck-hand who had been fishing for some time attended the clinic, was discovered to have mitral stenosis, and was certified as permanently unfit, but on leaving the clinic he joined a trawler only to be put ashore in Iceland. He returned to the clinic during his convalescence and reported that at 3.30 a.m. on the morning after his return from Iceland someone had come for him in a taxi to make up a trawler crew. Only after many protestations that he was ill did the taxi leave without him. More recently, a patient was discovered to be missing from the area mental hospital at Hull. A search for him by the police continued until three weeks later a report was received from a trawler returning to Hull that he was on board. He was met by the police and returned to hospital care.

\section{Appendix II}

\section{Further examples of injury and illness in Grimsby deep sea fishermen}

\section{Triple incidents in the same trawlerman}

(1) On July 5 off Iceland, a third hand was trapped by a wire rope while working on a spare trawl door, bruising his chest and back, but he continued his work at sea. He reported to the clinic, but did not have sick leave. On the next voyage, on July 30 , off the Faeroes, he complained of severe pains in the chest and the upper abdomen. His arms and shoulders felt heavy. These symptoms were reported by radio to a doctor at Stranraer Hospital and the skipper was advised that the trawlerman had had a heart attack and Tabs. Morphia, gr. $\frac{1}{4}$ six-hourly, were ordered. Next day the Stornaway lifeboat with a doctor on board met the vessel, the diagnosis was confirmed and the trawlerman was taken ashore to hospital at Stornaway. Personal communication with the hospital showed that there was no evidence of infarction on electrocardiographic examination and that a diagnosis of angina was made. In December, off Iceland, he pricked with a fish bone the third right finger which became infected but he had no days off at sea or ashore.

(2) In March, off Northern Iceland, a deck hand knocked his right knee and bruised it but remained at work. When he reported to the clinic it was noted that the bruising was over an exostosis of the tibial tuberosity. He returned to work and next trip, in the same month, again off Northern Iceland, the towing block struck his left hand, severing and amputating his little finger at the metacarpo-phalangeal joint and lacerating the palm of his hand. The skipper gave him two Tabs. Morphia gr. 1 and landed him in Norway. He was off work for 35 days. In September, 'off Russia', the ship took a heavy sea while he was working on the nets, knocking him over. He was struck in the left eye by a net hook, which lacerated the cornea. He was landed at Kirkenes. After medical treatment for two weeks he was flown to Grimsby where he was admitted to hospital for the removal of a fungating mass of granulation tissue which protruded from the inner aspect of the left eye. 
Injury

(1) A third hand was struck on the right side of the head by a steel bobbin weighing one and a half hundred-weight, when it slipped from a hook. He lost consciousness for about five minutes at the time of the accident but later returned to work. Two days later he collapsed and was landed at Honningsvag and received treatment for three weeks. Personal communication showed that he suffered from 'commotio cerebri'. When seen at the Grimsby Exchange Clinic, he complained of failing and double vision and was attending the Grimsby General Hospital as an out-patient. This man remained on Fisherman's Insurance Benefit for 19 months after his accident, when he was classified as permanently unfit for sea. A final settlement was made when he received the balance of $£ 750$ remaining after deduction of his weekly benefit.

(2) A deck hand had his left leg trapped by the warp in the middle bollard when shooting the trawl. He was incapacitated at sea for 11 days and landed at Siglufjord with a fracture of the left tibia and was flown immediately to Reykjavik Hospital. He was ashore for 100 days.

(3) A deck trimmer had his left arm trapped between the quarter rope and the winch drum and was landed at Akureyri, where he was found to have a fractured humerus. He had $\mathbf{1 1 2}$ days of incapacity ashore.

(4) A third deck hand had frostbite of all the fingers of the left hand which occurred in 'a black frost'. The ring finger was most severely affected and amputation of it and the little finger was carried out at the Grimsby General Hospital. Before his discharge from hospital he attended the rehabilitation unit. The frostbite occurred on December 20, 1963, but he had no logged incapacity at sea. He signed off his trawler on January 3, 1964, when he reported to the Grimsby Exchange Clinic. He did not return to sea and on December 8, 1965, was recorded as permanently unfit. He had no incapacity in 1963.

Illness

(1) A second engineer aged 43 suffered 'a rupture' in December 1963 after 'heavy lifting in the engine room'. On examination at the Grimsby Exchange Clinic, he was wearing a truss for a right inguinal hernia. His hospital records showed that he was very obese and had a history of multiple herniae. In 1958 he had had an operationt to repair an epigastric hernia. In 1961 he had an emergency admission for a strangulated umbilical hernia, 'a tender and irreducible swelling of the right end of a transverse umbilical incision scar'. In 1964 when examined at the out-patient department he had 'an incisional hernia and double inguinal herniae, the right larger than the left'. An abdominal belt was recommended for the former and he had operative repair of the inguinal hernia later in the year.

(2) 'Recurrence of previous stomach trouble': this was the logged report of an illness of an 18-year-old deck hand. The boy had had a renal operation in Iceland (the exact nature was not known) and suffered from recurrent haematuria (personal communication with his general practitioner). Ministry of Pensions and National Insurance records gave the diagnosis on the National Insurance Certificate as 'renal investigation'. He received 29 days of sickness benefit.

(3) A deck learner, off Southern Greenland, showed 'abnormal behaviour, inflicted wounds on himself and had to be locked in his cabin' (from the official log). On his return to Grimsby he was seen by the medical officer of the Grimsby Exchange Clinic. He had had a number of trips at sea over a period of three months. During this voyage he had made three attempts to jump overboard and had burned himself with matches, scratched his face, and eaten his faeces. A crew member discovered him with his hands in the galley fire and a bowl of custard on his head. The skipper said he had been a good worker and was liked by the crew but he had been worried about his mother and what his father would do to her in his absence. The father had had hospital treatment for mental illness on two occasions. The deck learner was admitted to hospital. At his mother's request he took his discharge against medical advice two months after the onset of his illness. When seen by the medical officer of the Grimsby Exchange Clinic on his return from sea, he was recorded as permanently unfit for sea. When he left the hospital he worked as a barrow boy for two months and was then allowed to return to sea, but only in North Sea trawlers. Three months later he sailed again to the Icelandic fishing grounds.

Received for publication May 4, 1968. 